\title{
Calc-alkaline volcanic rocks and zircon ages of the late Tonian: early Cryogenian arc-related Big Naryn Complex in the Eastern Djetim-Too Range, Middle Tianshan block, Kyrgyzstan
}

\author{
Baiansuluu Terbishalieva ${ }^{1,2,4}$ (D) Martin Jan Timmerman ${ }^{1} \cdot$ Alexander Mikolaichuk $^{2,4} \cdot$ Uwe Altenberger $^{1}$. \\ Jiří Sláma ${ }^{3} \cdot$ Anja Maria Schleicher $^{5} \cdot$ Masafumi Sudo $^{1} \cdot$ Edward R. Sobel $^{1}$ (D) $\cdot$ Sarah B. Cichy ${ }^{1,5}$
}

Received: 1 April 2020 / Accepted: 28 October 2020 / Published online: 24 November 2020

(c) The Author(s) 2020

\begin{abstract}
The Big Naryn Complex (BNC) in the East Djetim-Too Range of the Kyrgyz Middle Tianshan block is a tectonized, at least $2 \mathrm{~km}$ thick sequence of predominantly felsic to intermediate volcanic rocks intruded by porphyric rhyolite sills. It overlies a basement of metamorphic rocks and is overlain by late Neoproterozoic Djetim-Too Formation sediments; these also occur as tectonic intercalations in the BNC. The up to ca. $1100 \mathrm{~m}$ thick Lower Member is composed of predominantly rhyolitesto-dacites and minor basalts, while the at least $900 \mathrm{~m}$ thick pyroclastic Upper Member is dominated by rhyolitic-to-dacitic ignimbrites. Porphyric rhyolite sills are concentrated at the top of the Lower Member. A Lower Member rhyolite and a sill sample have LA-ICP-MS U-Pb zircon crystallization ages of 726.1 $\pm 2.2 \mathrm{Ma}$ and $720.3 \pm 6.5 \mathrm{Ma}$, respectively, showing that most of the magmatism occurred within a short time span in the late Tonian-early Cryogenian. Inherited zircons in the sill sample have Neoarchean (2.63, $2.64 \mathrm{Ga})$, Paleo- (2.33-1.81 Ga), Meso- (1.55 Ga), and Neoproterozoic (ca. $815 \mathrm{Ma})$ ages, and were derived from a heterogeneous Kuilyu Complex basement. A $1751 \pm 7 \mathrm{Ma}{ }^{40} \mathrm{Ar} /{ }^{39} \mathrm{Ar}$ age for amphibole from metagabbro is the age of cooling subsequent to Paleoproterozoic metamorphism of the Kuilyu Complex. The large amount of pyroclastic rocks, and their major and trace element compositions, the presence of Neoarchean to Neoproterozoic inherited zircons and a depositional basement of metamorphic rocks point to formation of the BNC in a continental magmatic arc setting.
\end{abstract}

Keywords Tianshan orogenic belt $\cdot$ Big Naryn complex $\cdot$ Tonian-Cryogenian $\cdot$ Magmatic arc $\cdot$ Calc-alkaline $\cdot$ Kuilyu complex

\section{Introduction}

Electronic supplementary material The online version of this article (https://doi.org/10.1007/s00531-020-01956-z) contains supplementary material, which is available to authorized users.

Baiansuluu Terbishalieva

bayansuluu2011@mail.ru

1 Institute of Geosciences, University of Potsdam, 14476 Potsdam, Germany

2 Institute of Geology, National Academy of Sciences, Erkindik Avenue-30, Bishkek 720481, Kyrgyzstan

3 Institute of Geology, The Czech Academy of Sciences, Prague 16500, Czech Republic

4 Northern-Kyrgyz Geological Expedition, Chu Area, Ivanovka 725008, Kyrgyzstan

5 Helmholtz Centre Potsdam, GFZ German Research Centre for Geosciences, Telegrafenberg, 14473 Potsdam, Germany
Volcanic and plutonic rocks are widespread in the central part of the Kyrgyz Middle Tianshan block (MTS) and were long considered as part of a once-continuous continental arc related to eastward subduction of oceanic crust below the MTS (e.g., Alexeiev et al. 2011; Safonova et al. 2017). However, correlations between the various volcanicplutonic units, such as the Big Naryn and Sary-Djaz units, remain uncertain. In the Kyrgyz part of the MTS, volcanic and plutonic rocks extend in a north-south direction from the contact with the North Tianshan (NTS) to the South Tianshan blocks (STS) and overlie and intrude Precambrian igneous and metamorphic units of the MTS, including the telescoped units in the study area, the East Djetim-Too Range (Fig. 1a-c). The discontinuous nature of the magmatic arc in the MTS is the result of a complex tectonic setting during the Paleozoic, which involved intracontinental 


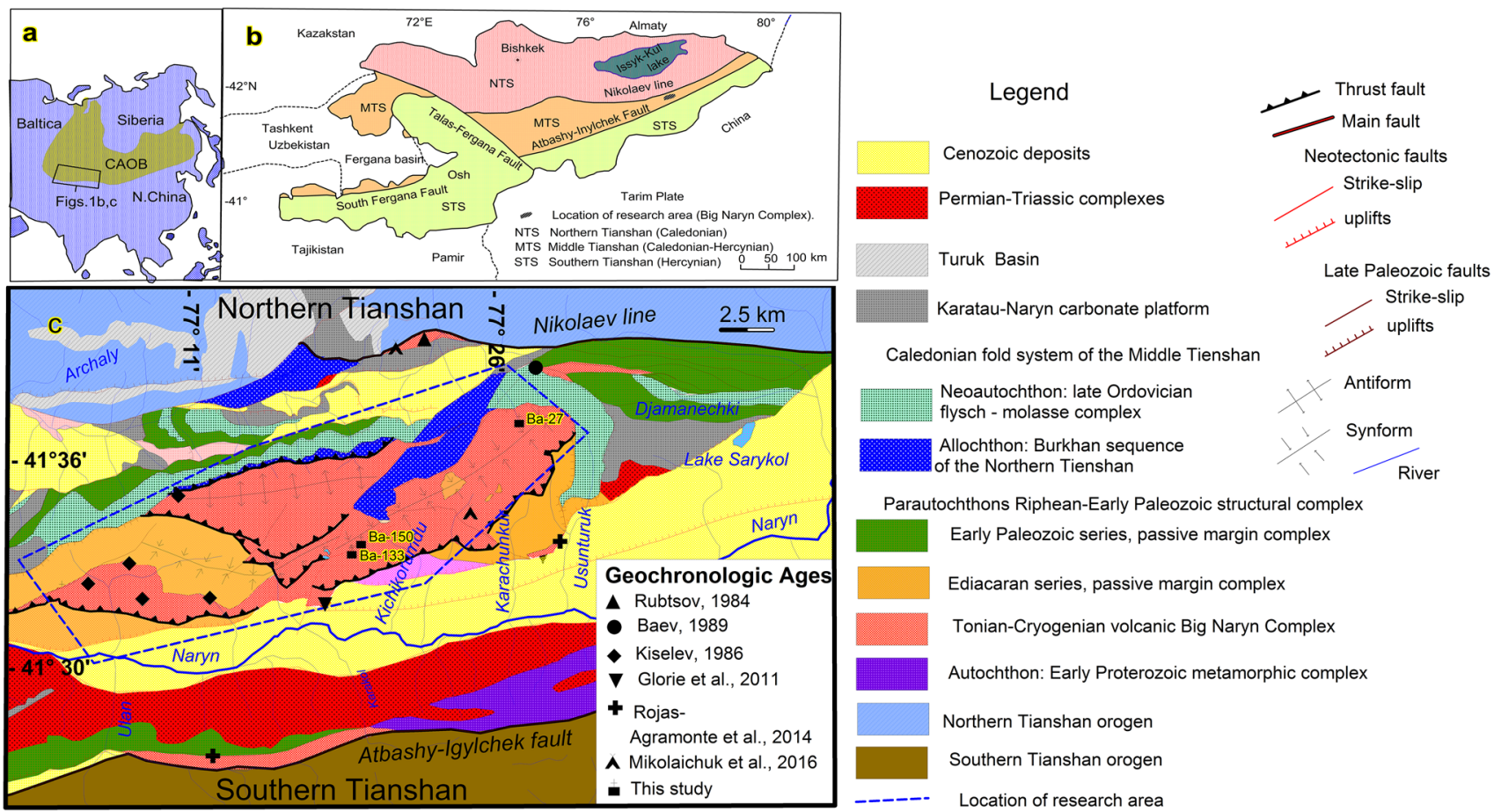

Fig. 1 The main structural units of the Tianshan Range. a Location of the Central Asian Orogenic Belt (CAOB) in Asia modified after Safonova (2017). b Borders of Kyrgyzstan showing (ultra-)high-pressure units and main tectonic elements, modified after Bakirov et al.

extension and probably arc break-up and dispersion related to the opening of the Sak and Ishym-Karatau paleo-oceans in the Early Paleozoic (Bakirov et al. 2014; Alexeiev et al. 2019). Later, early Paleozoic oblique subduction of oceanic crust and accretion of the STS continent in the Carboniferous (Hegner et al. 2010; Alexeiev et al. 2011; Terbishalieva 2018 [327-343 Ma]) played an additional role; long distance strike-slip transfer of arc segments has been suggested for the volcanic units in the Djetim-Too Range (Şengör et al. 1993; Mikolaichuk et al. 2016).

Abundant volcanic and sub-volcanic rocks are exposed in the East Djetim-Too Range (NE Kyrgyzstan) known as the Big Naryn Complex (BNC) but have not been studied in detail. Consequently, its role has not been fully taken into account in regional geodynamic models. U-Pb zircon ages of 842-760 Ma indicate Tonian-to-Cryogenian crystallization ages for the plutonic and volcanic rocks in the eastern Djetim-Too Range (summarized in Table 1; Kiselev et al. 1986, 1993; Glorie et al. 2011; Kröner et al. 2013; Bakirov et al. 2014; Mikolaichuk et al. 2016), but the geological significance of the large age range remains unclear. Although geochemical and age data were not available, the consensus was that the (sub-)volcanic rocks have a subduction-related origin (Bakirov et al. 2014).
(2014). c Simplified geology of the Djetim-Too Range (without Quaternary sediments) with locations of dated samples; modified after Mikolaichuk et al. (2016)

Kiselev et al. (1993) reported U-Pb multi-grain zircon upper intercept ages that range widely between ca. $716 \mathrm{Ma}$ and ca. $1280 \mathrm{Ma}$. Apart from many Mesoproterozoic and earliest Paleoproterozoic zircon ages, Glorie et al. (2011) also obtained a U-Pb spot ablation age for one zircon from gneiss of the Atbashi Metamorphic Complex of $788 \pm 26$ Ma. A felsic sill cutting the Atbashi Metamorphic Complex in the same area yielded an $842 \pm 16$ Ma zircon crystallization age and contains inherited zircons with ages in the range of 1866-2060 Ma (this sample was reported as a felsic tuff by Glorie et al. (2011)). Rojas-Agramonte et al. (2014) reported a zircon crystallization age of $836 \pm 4 \mathrm{Ma}$ for a dacite sampled as a clast in a late Neoproterozoic diamictite of the Djetim-Too Formation in the West Djetim-Too Range. Detrital zircons within the clastic diamictite matrix from the same area yielded ages in the range of $629 \pm 8$ to $2345 \pm 20 \mathrm{Ma}$ (Rojas-Agramonte et al. 2014).

The rocks exposed in the East Djetim-Too Range (EDTR) constitute a narrow domain that extends from Lake Issyk-Kul in the north to the western Kyrgyz Range in the south (Fig. 1b). It contains metamorphosed basement rocks of the Kuilyu Complex, Neoproterozoic volcanic rocks of the Big Naryn Complex (this study) and younger Neoproterozoic, glaciogenic rocks of the DjetimToo Formation of the Late Vendian to Early Cambrian 
Table 1 Published zircon ages for the Big Naryn Complex, Djetin-Too Formation (Middle Tienshan), Djetim-Too Range, and the Archaly area (North Tienshan)

\begin{tabular}{|c|c|c|c|c|c|c|}
\hline Sample No. & Rock & Latitude & Longitude & $\begin{array}{l}\text { Zircon age (Ma) } \\
\text { Older ages in parenthe- } \\
\text { ses }()\end{array}$ & Laboratory, method & References \\
\hline 10,538 & Plagiogranite & $41,705,326$ & $77,651,654$ & $791(1016) *$ & $\begin{array}{l}\text { Institute of Geology } \\
\text { NAS KR, ID-TIMS }\end{array}$ & Rubtsov (1984) \\
\hline 4528 & Rhyolite & $4,179,173$ & $7,812,271$ & $764 *$ & $\begin{array}{l}\text { Institute of Geology } \\
\text { NAS KR, ID-TIMS }\end{array}$ & Baev (1989) \\
\hline 4029 & $\begin{array}{l}\text { Subvolcanic granosy- } \\
\text { enite }\end{array}$ & $4,198,779$ & $7,841,915$ & $791 *$ & $\begin{array}{l}\text { Institute of Geology } \\
\text { NAS KR, ID-TIMS }\end{array}$ & Baev (1989) \\
\hline $57-85$ & Rhyolite & $41,561,111$ & $77,391,389$ & $825 \pm 20$ & $\begin{array}{l}\text { Institute of Geology } \\
\text { NAS KR, ID-TIMS }\end{array}$ & Kiselev et al. (1986) \\
\hline $9-81 \mathrm{a}$ & Rhyodacite & $4,151,944$ & $7,711,342$ & $801 *$ & $\begin{array}{l}\text { Institute of Geology } \\
\text { NAS KR, ID-TIMS }\end{array}$ & Kiselev et al. (1986) \\
\hline $9-81 b$ & Rhyodacite & $4,151,944$ & $7,711,342$ & $836 *$ & $\begin{array}{l}\text { Institute of Geology } \\
\text { NAS KR, ID-TIMS }\end{array}$ & Kiselev et al. (1986) \\
\hline $210 \mathrm{a}$ & Rhyodacite tuff & $4,149,623$ & $7,650,879$ & $692 *$ & $\begin{array}{l}\text { Institute of Geology } \\
\text { NAS KR, ID-TIMS }\end{array}$ & Kiselev et al. (1986) \\
\hline $210 \mathrm{~b}$ & Rhyodacite tuff & $4,149,623$ & $7,650,879$ & $716 \pm 20(820-1280)$ & $\begin{array}{l}\text { Institute of Geology } \\
\text { NAS KR, ID-TIMS }\end{array}$ & Kiselev et al. (1986) \\
\hline AI-31 & Tuff (see text) & $4,173,667$ & $7,806,639$ & $842 \pm 16(2057 \pm 55)$ & Ghent, LA-ICP-MS & Glorie et al. (2011) \\
\hline KG 22 & Rhyolite & $4,149,144$ & $7,640,936$ & $764 \pm 4$ & Beijing, SHRIMP II & Kröner et al. (2013) \\
\hline JT-4 & Subvolcanic rhyolite & $4,156,111$ & $7,739,139$ & $\begin{array}{l}747 \pm 58(877 \pm 17) \\
\quad(1691 \pm 30)\end{array}$ & Potsdam, LA-ICP-MS & Mikolaichuk et al. (2016) \\
\hline KG 20 & $\begin{array}{l}\text { Dacite clast (Djetim- } \\
\text { Too Fm.) }\end{array}$ & $4,127,022$ & $7,617,573$ & $836 \pm 4(2340)$ & Beijing, SHRIMP II & $\begin{array}{l}\text { Rojas-Agramonte et al. } \\
\text { (2014) }\end{array}$ \\
\hline AB-3462 & $\begin{array}{l}\text { Granite (Archaly, North } \\
\text { Tienshan) }\end{array}$ & $4,615,172$ & $7,744,412$ & $743 \pm 7(847 \pm 60)$ & $\begin{array}{l}\text { St. Petersburg, SHRIMP } \\
\text { II }\end{array}$ & Mikolaichuk et al. (2016) \\
\hline
\end{tabular}

ID-TIMS isotope dilution thermal ionization mass spectrometry, LA-ICP-MS laser ablation inductively coupled plasma mass spectrometry, SHRIMP sensitive high-resolution ion microprobe

*Reported without analytical uncertainties

Djetim Group (Chumakov 2009, 2011). In summary, it probably constitutes a crustal fragment or basement-cored horst.

Neoproterozoic arc rocks appear to be widespread in the MTS (Safonova 2017); however, reliable data on the internal structure, thickness, geochemistry and age of the Neoproterozoic BNC are limited. This study presents whole-rock major and trace element analyses of volcanic rocks and sills of the BNC to establish their composition and geological setting, and two new $\mathrm{U}-\mathrm{Pb}$ zircon ages from a rhyolite lava and a rhyolite sill to determine the age of the BNC. In addition, ${ }^{40} \mathrm{Ar} /{ }^{39} \mathrm{Ar}$ step-wise heating dating of amphibole from a metagabbro of the Kuilyu Complex was carried out to obtain a minimum age for the amphibolite-facies metamorphism of the basement, and to confirm the field relations between the Kuilyu and Big Naryn complexes. The results are discussed in combination with published studies to better assess the geodynamic implications of Neoproterozoic magmatism in the MTS.

\section{Regional setting}

The BNC is exposed in the eastern part of the $690 \mathrm{~km}^{2}$ Djetim-Too Range. The tectonic map of the BNC was assembled by Mikolaichuk et al. (2016) and was accepted as the basis for the geological map of the East Djetim-Too Range (EDTR) by the Geological Survey of Kyrgyzstan. The study area is situated in what is known in the Russian language literature as the "Djetim geosynform zone" of the MTS.

The Kyrgyz Tianshan is subdivided into three tectonic zones. The Middle Tianshan block (MTS) occurs between the North Tianshan (mainly early Paleozoic accretionary complexes) and the South Tianshan block (a late Paleozoic fold and thrust belt) and comprises Precambrian metamorphic units, late Neoproterozoic magmatic and glaciogenic rocks as well as middle Devonian to late Carboniferous limestones and clastic sediments, deformed in the late Paleozoic (Alexeiev et al. 2019, and references therein). 
The MTS has been labelled as a composite terrane, superterrane or allochthonous geological province (Mikolaichuk et al. 2016). To the south, the MTS is bounded by the Atbashi-Inylchek fault against the South Tianshan block, and to the north by the "Nikolaev Line" or "Main structural line of the Tianshan" (Fig. 1b), against the North Tianshan block. The Nikolaev Line is a strike-slip fault that possibly formed in the Permian-Triassic, and was reactivated in the Cenozoic (Korolev 1956; Mikolaichuk and Dzhenchurayeva 2000; Bazhenov and Mikolaichuk 2004).

\section{Geology of the East Djetim-Too Range}

\section{Big Naryn complex}

Neoproterozoic volcanic rocks are well exposed in the East Djetim-Too Range, in contrast to other parts of the MTS, where they are either divided by numerous faults or not exposed at all. No reliable stratigraphic framework existed for the upper Neoproterozoic volcanic sequence of this study area. Schulz (1948) was the first to report the presence of volcanic rocks and named it the "quartz porphyry of the Naryn anticline" after the nearby Bolshoi (big) Naryn River. The majority of later published studies noted that the volcanic complex in the EDTR is made up of volumetrically dominant felsic pyroclastic and effusive rocks that are intruded by rhyolitic sills, and it was subsequently described as the "large assemblage of Naryn" or the "Big Naryn" complex (Korolev 1956; Dodonova and Goretskaya 1972; Sagyndykov and Sudorgin 1984; Kiselev 1993).
The Big Naryn Complex makes up to $40 \%$ of the study area (EDTR) and occupies the slopes and watershed of the upper parts of the Djetim-Too Range, with the remaining $60 \%$ covered by Cenozoic sediments and glaciers (Fig. 1c). The volcanic rocks, together with the overlying Djetim Formation of younger Neoproterozoic basal conglomerates (containing BNC-derived clasts) and diamictites, make up several north-vergent tectonic sheets. Accordingly, the primary stratigraphic sequence of the formation is restored based on the correlation of a series of partial geological sections mapped between 2010 and 2014 on the exposed southern and northern slopes of the range. This geological field work was led by the Northern Kyrgyz Geological Expedition (northern branch of the Kyrgyz Geological Survey), in which the first author (BT) was actively involved. Based on field observations and thin section petrography performed for this study and Terbishalieva (2018), the sequence was subdivided into a Lower Member of predominantly rhyolite and rhyodacite lavas and tuffs with subordinate basalt flows, and an Upper Member largely composed of dacitic to rhyolitic ignimbrites. Discordant porphyric rhyolite sills are situated mainly at the top of the Lower Member and intruded into zones of weakness, such as faults and along the contact between the Lower and Upper Members (Fig. 2). Dykes, stocks and plutons are not present.

In the East Djetim-Too Range, BNC lithologies occur tectonically intercalated with rocks of the Djetim-Too Formation and Kuilyu Complex (Fig. 1c). Metagabbro, metadolerite and chlorite-mica schists of the Kuilyu Complex were only found in and along main thrusts that also placed conglomerates and diamictites of the Djetim-Too Formation

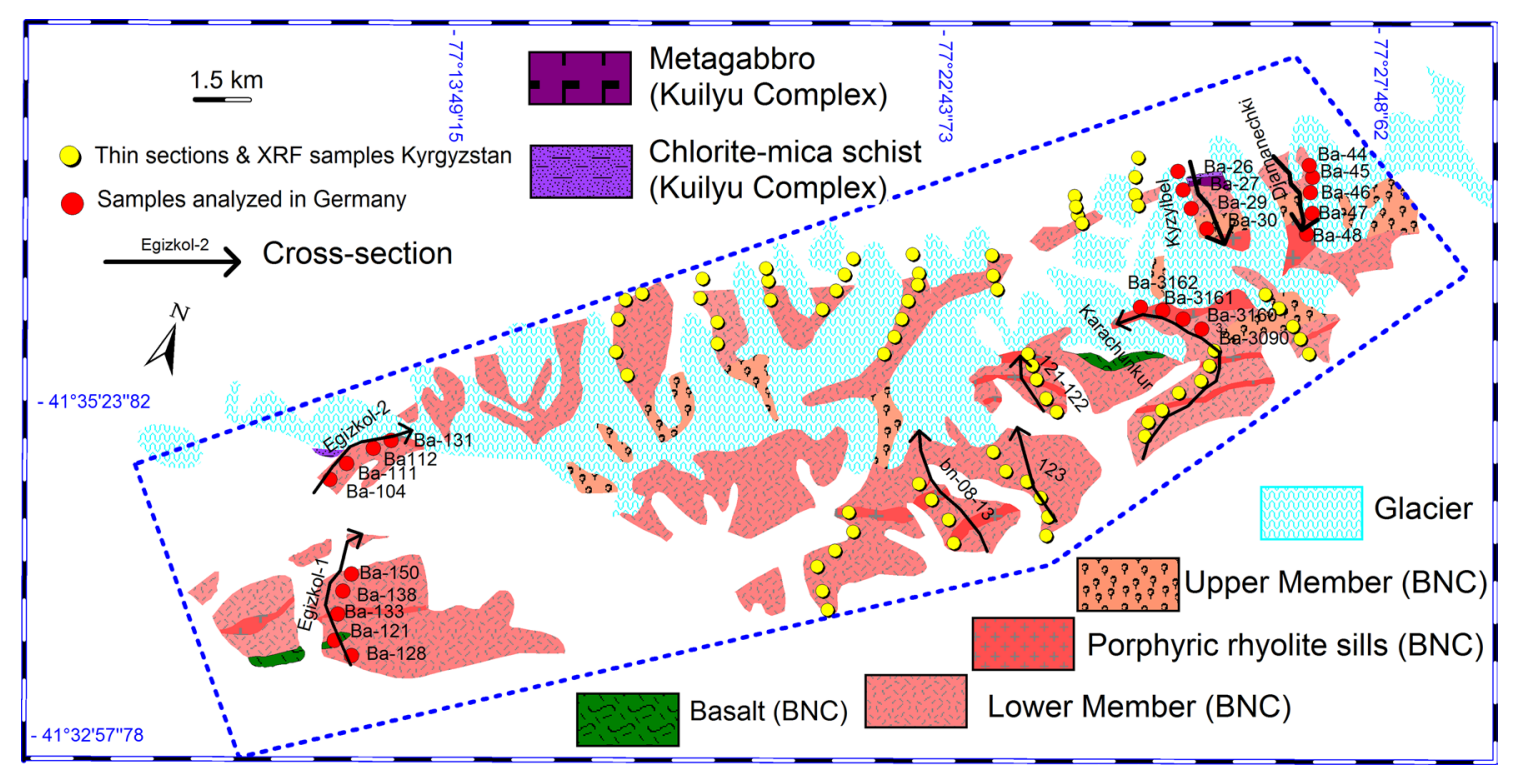

Fig. 2 Mapped cross-sections Egizkol-1, Egizkol-2, bn-08-13, 121, 122, 123, Karanchunkur, Kyzylbel and Djamanechki, with sample locations 
onto rocks of the BNC (e.g. cross-section 123 in Online Resource 1).

Accordingly, the primary stratigraphic sequence in the East Djetim-Too Range is restored based on the correlation of a series of cross-sections (Figs. 2 and 3) mapped on the southern and northern slopes of the range (Online Resource 1). The cross-sections show that the BNC constitutes a faulted sequence of lavas and tuffs containing sill intrusions. Korolev (1956) and Kiselev (1984) found that greenschist-facies metamorphism of the BNC had developed along the "Nikolaev Line", and Dodonova and Goretskaya (1972) noted that the metamorphism had only developed locally and that primary structures and textures of lavas, pyroclastic rocks, and the sills are generally well preserved macroscopically and in thin section.

\section{Kuilyu Complex}

Schulz (1948) noted that the Big Naryn Complex unconformably overlies metamorphic rocks of the Kuilyu Complex in the Irisu River, the left tributary of the Naryn River (Korolev and Maksumova 1984). Sagyndykov et al. (1988) described felsic effusive rocks of the BNC overlying quartzites and marbles of the Kuilyu Complex in the eastern, Akshiyrak part of the EDTR. Hence, the Kuilyu Complex formed the original depositional basement to the BNC.

The Kuilyu Complex in the Middle Tienshan Block is at least $2500 \mathrm{~m}$ thick and is mainly made up of amphibolite-facies metasediments, metabasalts, metagabbros and granitoid migmatites that underwent a greenschistfacies overprint. For the Sary-Djaz area to the east of the EDTR, Mikolaichuk et al. (2008) cite an imprecise $2431 \pm 200 \mathrm{Ma}$ K-Ar amphibole age for Kuilyu Complex amphibolite, and much younger 646-950 Ma K-Ar ages for amphibole and (altered) biotite from Sary-Djaz granitoids. Locally, metadolerites, metagabbros and chlorite-mica schists of the Kuilyu Complex occur intercalated with the Lower Member lithologies of the BNC, as shown particularly in cross-sections Kyzykbel, Karachunkur and number 123 (Online Resource 1).

In addition, the $\mathrm{BNC}$ was thrust northwards over younger, late Neoproterozoic glaciogenic sediments of the Djetim-Too Formation (e.g. sections Kyzybel, 123 and bn-08-13, Online Resource 1), while the latter are also present among and between BNC lithologies within thrust-bound units (e.g. the Karanchunkur section). Thus, during northwards thrusting of the BNC, fragments or sheets of both basement material and overlying Djetim-Too Formation sediments were incorporated.

\section{Djetim-Too Formation}

The Djetim-Too Formation of diamictites and conglomerates occurs widespread in the Middle Tienshan Block, and in the study area is locally tectonically intercalated with BNC and basement rocks. It was originally unconformably deposited onto the BNC and constitutes the lowest part of the tripartite Djetim Group that comprises the lower Djetim-Too Formation, the middle Dzhakbolot Formation of variegated carbonates and shales and the upper Baykonur Formation of upper Ediacaran glacial deposits (Chumakov 2009). Both diamictite formations contain locally derived clasts of BNC rocks and comprise thin-bedded shales with dropstones (Chumakov 2009). Microfossils (microphytolites) point to a Neoproterozoic deposition age for the Djetim-Too Formation (Mikolaichuk et al. (2008) and references therein).

The Djetim-Too Formation in the EDTR is made up of different terrigenous rocks (conglomerates, gravelites,

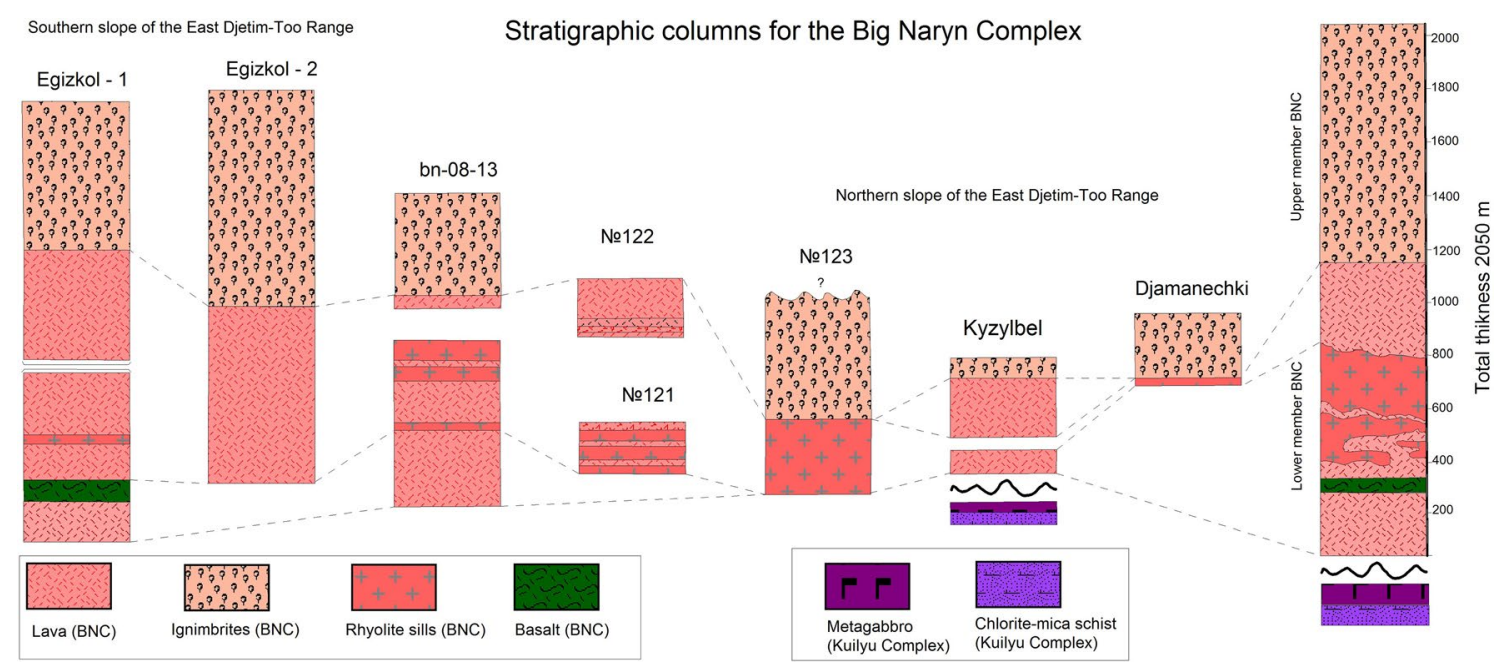

Fig. 3 Composite stratigraphic column (right) based on eight mapped cross-sections shown in Fig. 2 
sandstones, siltstones, shales) and mixed, debris-like rocks that are typically very weakly sorted and tillite-like. They are found as dark gray or greenish-gray clastic rocks containing rare pebbles, boulders and blocks of volcanic rocks and limestone. The Djetim-Too Formation is overlain by the Dzakbolot Formation that starts with up to $10 \mathrm{~m}$ carbonaceous limestones that may be the equivalents of post-glacial cap carbonates (Chumakov 2009).

\section{Petrography}

Abbreviations for rock-forming mineral names are from Whitney and Evans (2010).

\section{Lower Member of the Big Naryn Complex}

The Lower Member is dominated by rhyolite to dacite lavas, which are interlayered with tuffs and tuff-derived sediments (Fig. 4a). Rhyolites and rhyodacites have a fine-grained groundmass with a flow fabric containing small, idiomorphic, up to $1 \mathrm{~mm}$-sized phenocrysts of quartz and feldspar, the latter albitized to various degrees (Fig. 4d). The amount of phenocrysts is less than $10 \%$ of the rock volume. The bulk of the planar fabric is microcrystalline (Fig. 4d). Rhyolitic and rhyodacitic tuffs vary from coarse-grained litho-, vitro- and crystalloclastic, volcano-sedimentary breccias to medium-grained crystalloclastic and fine-grained tuffaceous volcanoclastic rocks. Lithoclasts are fine- to very fine-grained volcanic rocks (felsite, micro-felsite) and porphyric rhyolites with millimeter-sized phenocrysts of mostly alkaline feldspar. In crystalloclastic tuffs, sharply angular quartz fragments dominate, plagioclase is rare, and the rocks are highly sericitized. Tuffaceous sedimentary rocks are finegrained tuffaceous siltstones (Fig. 4a).

Thin basalt lavas occur in the lower part of the Lower Member. They are dark green and all samples are altered except for analyzed sample Ba-121, which is relatively fresh. Most are porphyric with phenocrysts of monoclinic pyroxene (augite) forming 0.5-1 mm-sized idiomorphic prisms that are nearly colorless with a weak greenish tinge. Groundmasses composed of former plagioclase and clinopyroxene have intersertal textures and amygdales are filled with secondary chlorite and feldspar (Fig. 4b). Opaque minerals are relatively large and may be primary magmatic.

\section{Upper Member of the Big Naryn Complex}

In contrast to the Lower Member, the Upper Member is characterized by a larger variety of rock types comprising rhyolitic, rhyodacitic, and dacitic ignimbrites with thin lavas and tuffs. The ignimbrites are enriched in ore minerals such as magnetite, chalcopyrite and pyrite. Volcanic and volcanoclastic breccias contain angular or flattened rhyolite and dacite fragments of widely varying sizes from several millimeters to $10 \mathrm{~cm}$. The groundmass is cryptocrystalline and locally shows eutaxitic textures (Fig. 4e). Ignimbrites of rhyodacitic and dacitic composition are darker compared to the rhyolitic ignimbrites, and their textures vary from cryptocrystalline to fine-grained to eutaxitic. Segregation lenses and fiamme are noticeable and can be recognized by their shapes, color and (in some samples) compositions, with fiamme rims enriched in finely dispersed ore minerals causing darkening. Crystals are quartz, plagioclase and, less often, alkali-feldspar now completely replaced by albite. Crystal shapes range from isometric, comminuted to irregular with sinuous outlines. The groundmass of baked vitric tuffs is black (Fig. 4e).

\section{Porphyric rhyolite sills}

The porphyric rhyolite sills can be distinguished from porphyric rhyolite lavas by their textures. The textural variations of the sill lithologies range from aphyric to porphyric rhyolites. In endocontact zones and in thin bodies, textures vary from porphyric to aphyric, locally perlitic (Ba-130), and groundmass textures vary from fine-grained (Ba-133) to microgranophyric and granophyric (Fig. 4c). Small phenocrysts up to $0.5 \mathrm{~mm}$ in size are represented by quartz, alkali-feldspar (in some samples nearly completely albitized), and rare plagioclase. In the central parts of the rhyolitic sills, phenocrysts of several generations constitute up to $15-20 \%$ of the rock volume. Among the large grains of the first generation, with sizes up to $4 \mathrm{~mm}$, perthite predominates while quartz crystals, locally corroded down to $3 \mathrm{~mm}$, occur in subordinate amounts. Locally, granophyric intergrowths of quartz and orthoclase, as well as single plagioclase crystals (oligoclase) are present.

\section{Alteration and secondary minerals}

Samples from the Lower and Upper members and the porphyric rhyolite sills are altered to varying degrees, with propylitic alteration dominating the Upper Member lithologies. Most samples retained primary magmatic textures, but many are altered to various degrees, mostly propylitization with formation of dispersed pyrite, chalcopyrite, magnetite and hematite (Fig. 4f). In addition, sericitization of groundmass alkali feldspar is observed in thin section. Alteration is more common in the Upper Member than in the Lower Member; in the former, most of the fiamme are propylitized and seriticized to fine-grained secondary minerals. Veins and breccias are typically filled by propylitic alteration minerals, such as epidote, chlorite, with pyrite, chalcopyrite, magnetite and hematite as the main ore minerals. Alteration is mainly manifested as sericitization (Ba-49) and secondary silicification 


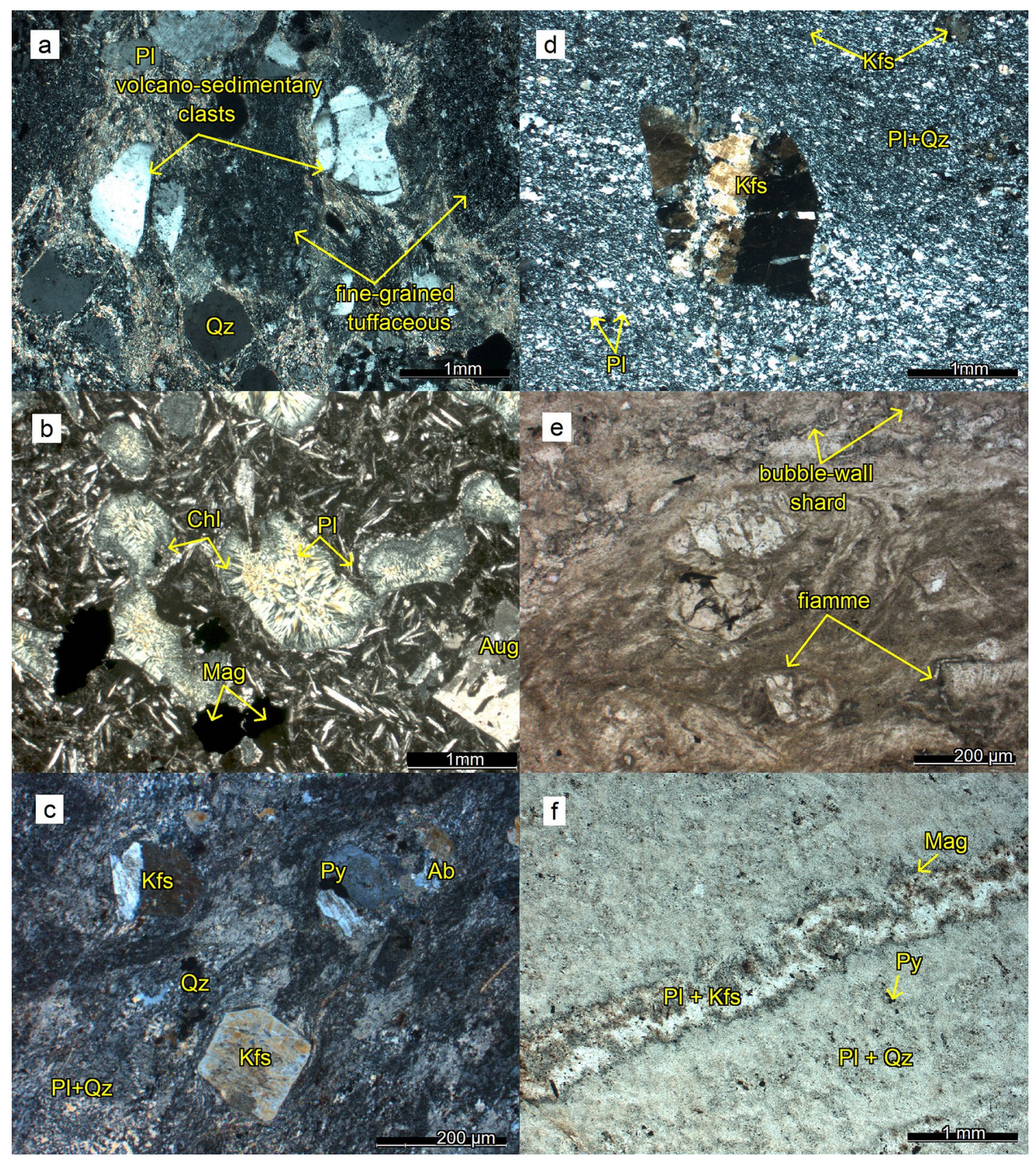

Fig. 4 Photomicrographs of selected samples. a Rhyolitic tuff groundmass with flow texture (Ba-2010), b altered basalt with spherical amygdales filled by chlorite (Ba-121), c porphyric rhyolite sill sample with felsite groundmass (Ba-133), $\mathbf{d}$ felsic lava showing alkali feldspar phenocryst in fine-grained groundmass (Ba-150), e ignim- brite with dark- colored fiamme and eutaxitic texture (Ba-30/2) and f planar fabric defined by modal variations in quartz, plagioclase and alkali feldspar (Ba-104) (a-d: cross-polarized light; e-f: plane polarized light)

occurred locally and appear to be related to the activity of the main faults and thrusts.

\section{Kuilyu Complex metagabbro}

The least altered metagabbro sample Ba-27 (Kyzylbel cross-section, Online Resource 1) that was selected for 
Fig. 5 a, $\mathbf{b}$ Thin section of amphibolite-facies metagabbro Ba-27 showing layers and lenses of recrystallized feldspar (light grey) and green lenses of hornblende and magmatic clinopyroxene remnants (a unpolarized light; $\mathbf{b}$ crosspolarized light). The foliation is highlighted. Size 28 by $48 \mathrm{~mm}$

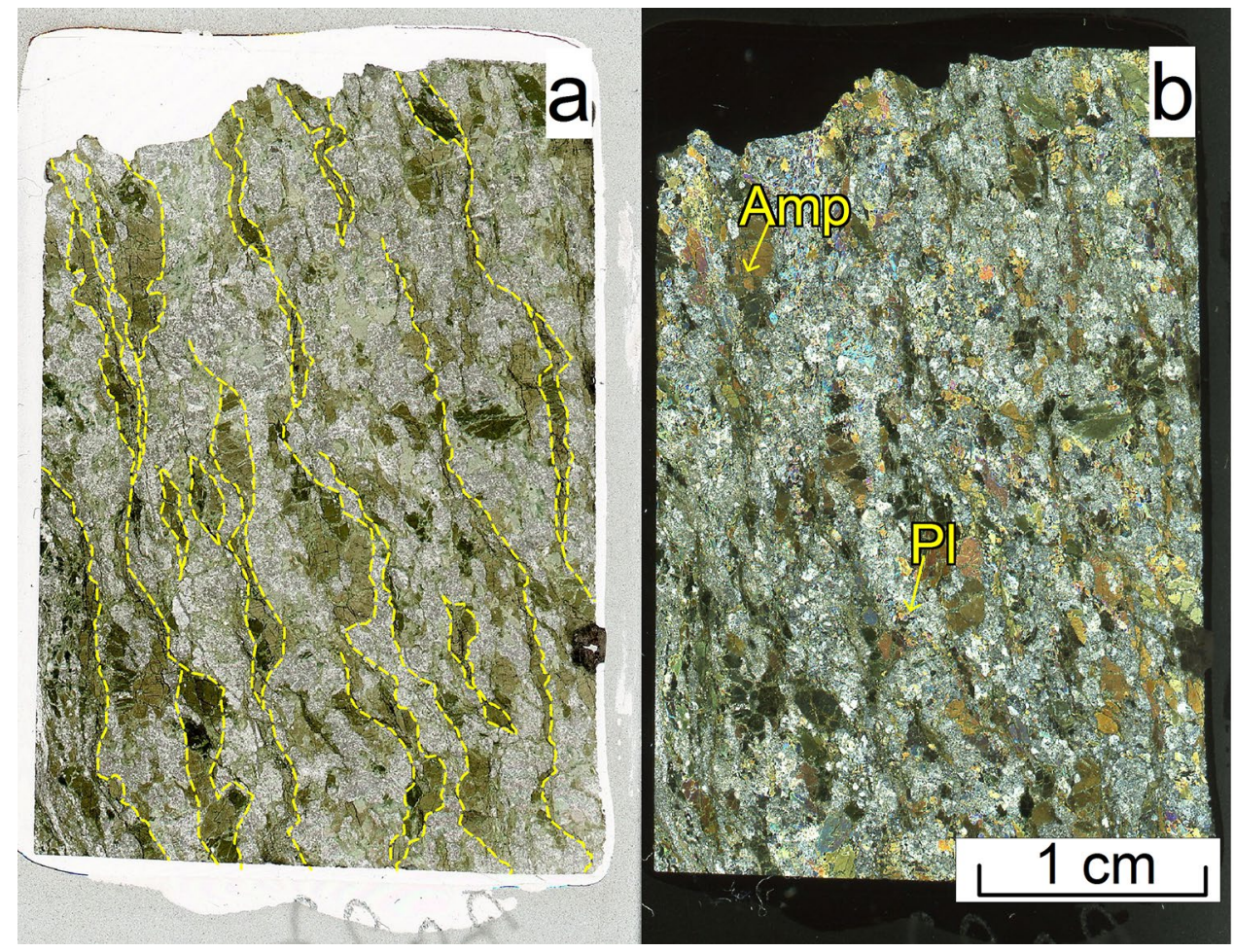

amphibole ${ }^{40} \mathrm{Ar} /{ }^{39} \mathrm{Ar}$ step-heating dating contains magmatic clinopyroxene remnants. It contains a planar fabric formed by mafic layers of mainly chlorite, epidote and amphibole (hornblende), and felsic layers made up of lens-shaped plagioclase and opaque minerals, mainly magnetite, hematite, pyrite and/or chalcopyrite (Fig. 5a, b). Most of the amphiboles occur as hypidiomorphic prisms showing undulose extinction.

\section{Sampling and analytical methods}

This study is based on a set of 73 rock samples collected during the period of 2014-2018. XRF major element whole rock analyses were carried out on all samples and a subset of 21 samples was analyzed for trace element concentration (Online Resources 2A and 2B). The sample set comprises 44 acid to intermediate volcanic rocks, 4 basalts and 25 rhyolite sill samples and one metagabbro of the Kuilyu Complex basement (Ba-27, Online Resource 2A).

A rhyolite (lava) with large alkali-feldspar phenocrysts from the Lower Member (Ba-150) and a porphyric rhyolite sill sample (Ba-133) were selected for $\mathrm{U}-\mathrm{Pb}$ zircon dating to determine crystallization ages and the timing of volcanism of the BNC. In addition, an amphibolite-facies metagabbro of the Kuilyu Complex (Ba-27) was chosen for ${ }^{40} \mathrm{Ar} /{ }^{39} \mathrm{Ar}$ amphibole step-heating dating to determine a cooling age for the basement and establish an upper age limit for its amphibolite-facies metamorphism.

\section{XRF and ICP-AES methods}

Altered surfaces and veins were removed from all samples prior to sample preparation and geochemical analysis.

59 whole rock analyses were carried out at the Geological Agency of Mineral Resource of the Kyrgyz Republic. After sample dissolution, $\mathrm{Al}_{2} \mathrm{O}_{3}, \mathrm{TiO}_{2}$, and $\mathrm{P}_{2} \mathrm{O}_{5}$ concentrations were determined by classical photo-voltaic colorimetry, using a KFK-2MP photo colorimeter in the $315-980 \mathrm{~nm}$ wavelength range. $\mathrm{CaO}, \mathrm{MgO}$ and $\mathrm{MnO}$ concentrations were determined by atomic absorption spectrometry, and $\mathrm{K}_{2} \mathrm{O}$ and $\mathrm{Na}_{2} \mathrm{O}$ by flame photometry. $\mathrm{SO}_{3}$ and Loss On Ignition (LOI) values were determined gravimetrically.

For the 24 whole rock analyses carried out in Germany, clean fragments were crushed with a jaw crusher and subsequently powdered, using an agate mill at the Institute of Geosciences of the University of Potsdam, Germany. The powdered rock samples were dried in an oven for more than $6 \mathrm{~h}$ at $105-110{ }^{\circ} \mathrm{C}$ before processing. Major oxide and selected trace element concentrations ( $\mathrm{Ba}, \mathrm{Cr}$, $\mathrm{Ga}, \mathrm{Nb}, \mathrm{Ni}, \mathrm{Rb}, \mathrm{Sr}, \mathrm{Y}, \mathrm{Zn}, \mathrm{Zr}$ ) were determined on fused lithium-tetraborate glass disks at the Helmholtz Centre Potsdam-GFZ German Research Centre for Geosciences, 
using a Phillips PW-2400 X-ray fluorescence (XRF) spectrometer. The detection limits for major oxides is $<0.01$ $\mathrm{wt} \%$ and $<10 \mathrm{ppm}$ for the trace elements. International natural standards were used for calibration and monitor analytical precision, which is better than $1-3 \%$ for major elements and better than 10\% for trace elements (Zuleger and Erzinger 1988).

The concentrations of $\mathrm{H}_{2} \mathrm{O}$ and $\mathrm{CO}_{2}$ were determined on $20 \mathrm{mg}$ of powdered samples weighed on tin foils using a Euro EA 3000 Elemental Analyzer at the University of Potsdam. Sulfanilic acid and BBOT (2.5-Bis-(5-tert-butyl2-benzo-oxazol-2-yl) thiophene) was used to calibrate the instrument. Internal natural and synthetic standards (sulfanilic acid, BBOT and Odinit) were used to monitor analytical precision. Measurements were carried out twice to check measurement precision, which is better than $1 \%$ (Dietrich and Schwandner 2004).

Scandium (Sc), yttrium (Y), and rare-earth element (REE) concentrations were determined by inductively coupled plasma atomic emission spectrometry (ICP AES) at the GFZ and the University of Potsdam. Sample dissolution was done at the University of Potsdam; rock powders were dissolved using standard $\mathrm{Na}_{2} \mathrm{O}_{2}$ fusion and dilution techniques (Zuleger and Erzinger 1988). The analytical accuracy of the method is $<1 \%$ and the precision for the REE ranges between 5 and $10 \%$ based on comparison with international reference standards. $1 \mathrm{~g}$ of powdered sample was mixed with $5 \mathrm{~g} \mathrm{NA}_{2} \mathrm{O}_{2}$ in a nickel crucible, then covered by $1 \mathrm{~g} \mathrm{Na}_{2} \mathrm{O}_{2}$ and heated at $500{ }^{\circ} \mathrm{C}$. After cooling down, deionized water was added to the sinter cake until the reaction stopped. The sinter cake was then taken up in $40 \mathrm{ml}$ deionized water, and the mixture was transferred to a centrifuge tube and centrifuged (Eppendorf Centrifuge 5702) for $15 \mathrm{~min}$ at $4000 \mathrm{ppm}$. To remove the soluble silica salts, the centrifugation procedure was repeated three times. After removing the solute from the sinter cake by decanting, the remaining sinter cake was dissolved in 1 molar $\mathrm{HCl}$ and $42 \mathrm{ml}$ deionized water and transferred to a $100 \mathrm{ml}$ bottle. Ion exchange columns were used for chromatographic separation of the Sc, Y and REE. $500 \mathrm{ml} 1.7$ molar $\mathrm{HCl}$ was used to elute the major constituents and most of the trace elements. Sc, Y and REE were eluted in $550 \mathrm{ml} 4$ molar $\mathrm{HCl}$. The eluates containing the Sc, $\mathrm{Y}$ and REE were filtered, evaporated and dried overnight. The residua were then dissolved in exactly $10 \mathrm{ml} 10 \% \mathrm{HCl}$ and stored in $10 \mathrm{ml}$ bottles. REE concentrations were determined using a Vista MPX at the Institute of Geosciences, University of Potsdam. Sc and $\mathrm{Y}$ were determined at the GFZ with an ICP-AES 5100 spectrometer, using a fast automated curve-fitting technique (FACT) correction model.

For the determination of $\mathrm{Hf}, \mathrm{Pb}, \mathrm{Th}, \mathrm{U}, \mathrm{Cs}$ concentrations, a selection of four samples covering all units, Ba-27 (metagabbro), Ba-150 (Lower Member rhyolite lava), Ba-46 (Upper Member ignimbrite) and Ba-133 (porphyric rhyolite sill), were crushed and powdered to less than $0.63 \mu \mathrm{m}$. Concentrations were determined at the GFZ by inductively coupled plasma mass spectrometry (ICP-MS), using a Perkin-Elmer/Sciex Elan Model 500 using the method of Dulski (1994). The major and trace element data are presented in Online Resources 2A and 2B.

\section{Zircon separation and LA-ICP MS analyses}

Heavy mineral concentration took place at the Institute of Geosciences, University of Potsdam. Rhyolitic lava Ba-150 from the Lower Member and porphyric rhyolite sill sample Ba-133 (both from the Egizkol-1 cross-section, Online Resource 1) were crushed and then sieved to $<500 \mu \mathrm{m}$. Subsequently, heavy minerals of the crushed samples were segregated with a Humboldt Wedag shaking table and then were cleaned in $10 \%$ acetic acid for over $12 \mathrm{~h}$ and in $3 \%$ $\mathrm{H}_{2} \mathrm{O}_{2}$ for more than $12 \mathrm{~h}$. Following separation of ferromagnetic grains using a hand magnet, the heavy mineral concentrates were repeatedly passed through a Frantz magnetic separator at increasing field strengths and angles of 12 , then $5^{\circ}$. Separator funnels filled with sodium polytungstate (SPT, 2.87 g. $\mathrm{ml}^{-1}$ ) were used to remove lighter minerals (e.g. quartz, feldspar) from the least magnetic fractions by floatation. The heavy fractions were washed with deionized water and dried at $>50^{\circ} \mathrm{C}$, followed by removal of heavier minerals (mainly apatite) by floatation in methylene iodide (MEI, $3.3 \mathrm{~g} \mathrm{ml}^{-1}$ ). The zircon-rich heavy fractions were first washed with acetone and dried.

At the Institute of Geology of the Czech Academy of Science in Prague, zircons were handpicked, mounted in epoxy and then polished. Their internal structures were documented by cathodoluminescence (CL) imaging and, after spot selection, these zircons were analyzed by laser ablation inductively coupled plasma mass-spectrometry (LA-ICPMS). A Thermo Scientific Element 2 sector field ICP-MS coupled to a 193-nm ArF excimer laser was used to measure the $\mathrm{Pb} / \mathrm{U}$ and $\mathrm{Pb}$ isotopic ratios in zircons. The laser was fired at a repetition rate of $5 \mathrm{~Hz}$ and fluence of $3.17 \mathrm{~J} / \mathrm{cm}^{2}$ with 20-micron spot size. The He carrier gas was flushed through the two-volume ablation cell at a flow rate of 0.75 $\mathrm{L} / \mathrm{min}$ and mixed with $0.81 \mathrm{~L} / \mathrm{min} \mathrm{Ar}$ and $0.004 \mathrm{~L} / \mathrm{min} \mathrm{N}$ prior to introduction into the ICP. The in-house glass signal homogenizer (design of Tunheng and Hirata 2004) was used for mixing all the gases and aerosol, resulting in smooth, spike-free signal. The signal was tuned for maximum sensitivity of $\mathrm{Pb}$ and $\mathrm{U}, \mathrm{Th} / \mathrm{U}$ ratio close to unity and low oxide level, commonly below $0.2 \%$. Typical acquisitions consisted of $15 \mathrm{~s}$ measurement of blank followed by measurement of $\mathrm{U}, \mathrm{Th}$, and $\mathrm{Pb}$ signals from the ablated zircon for another $35 \mathrm{~s}$. The total of 420 mass scans of data were acquired in time resolved-peak jumping-pulse counting mode with one point measured per peak for masses ${ }^{204} \mathrm{~Pb}+\mathrm{Hg},{ }^{206} \mathrm{~Pb},{ }^{207} \mathrm{~Pb}$, 

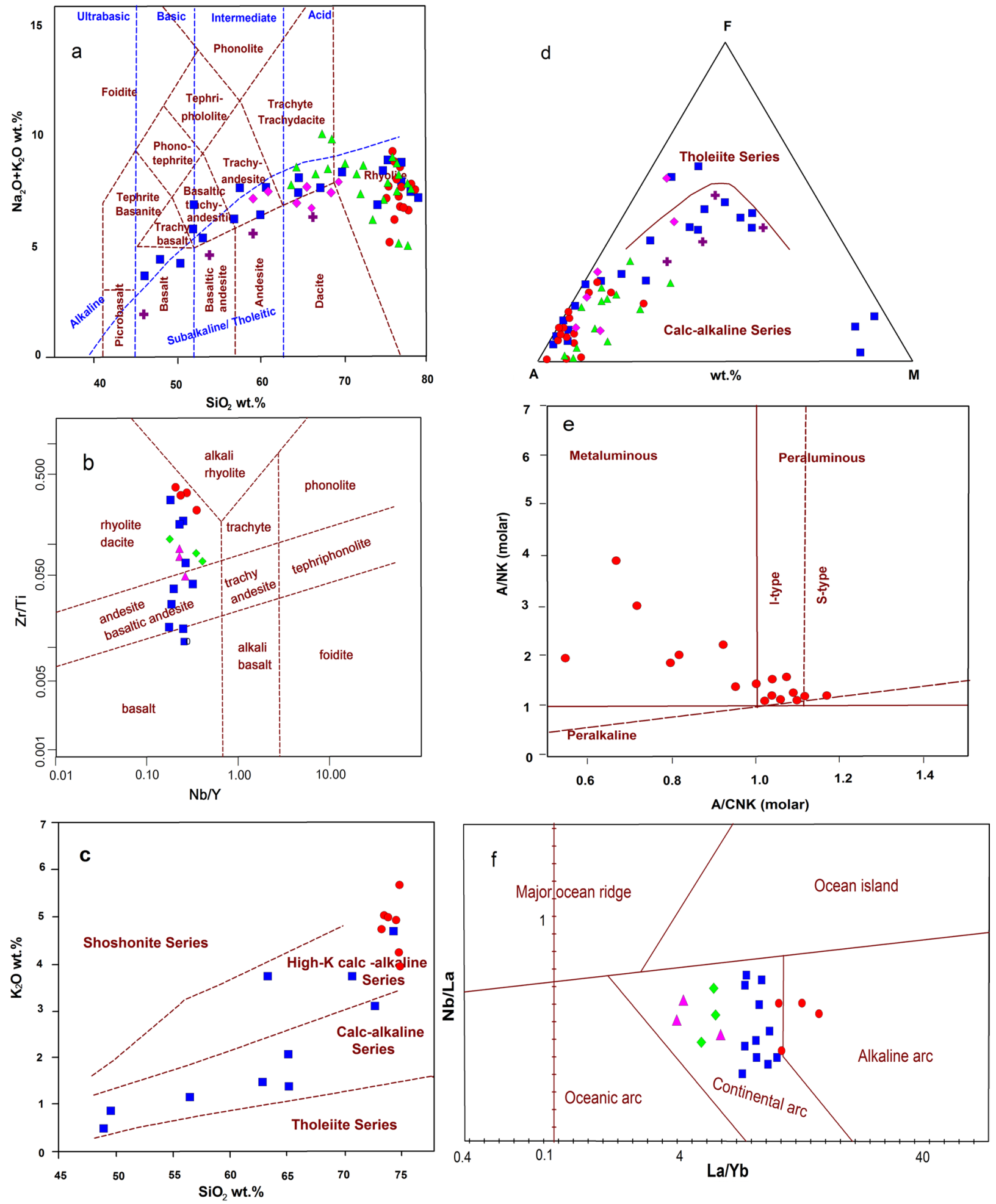

\section{Big Naryn Complex}

\section{- Lava $\Delta$ - Tuff $\diamond$ - Ignimbrite $\bigcirc$ - Porphyric rhyolite sill \$-Altered sample}


४Fig. 6 a Total alkalis vs. silica (TAS) diagram (Le Bas et al. 1986) showing most samples plotting in the subalkaline series field, with only 5 samples plotting in the alkaline series field. The lavas define a convex upward trend from basic to acid. Tuffs and ignimbrites start at intermediate compositions and trend towards acid compositions. Altered samples appear to have lost $\mathrm{Na}$ and $\mathrm{K}$, and plot below the trend (crosses). The porphyric sill samples are subalkaline and plot in the rhyolite field. b Nb/Y vs. Zr/Ti diagram of Pearce (1996) showing that the samples belong to the subalkaline series and define a basic to acid trend. $\mathrm{c} \mathrm{SiO}_{2}$ vs. $\mathrm{K}_{2} \mathrm{O}$ plot of Peccerillo and Taylor (1976). Basalt to rhyolite lava samples range between the calk-alkaline and high-K calk alkaline series. The sill samples are restricted to the high $\mathrm{K}$-alkaline series field. d AFM diagram showing that most of the samples form a calc-alkaline series, but that some altered samples plot in the tholeiite field. After Irvine and Baragar (1971). e Aluminum saturation (A/CNK vs. A/NK) diagram of Maniar and Piccoli (1989) for sill samples, showing a range from metaluminous to peraluminous compositions. $f \mathrm{Nb} / \mathrm{La}$ vs $\mathrm{La} / \mathrm{Yb}$ diagram showing the volcanic rocks of the Big Naryn Complex plotting in the continental arc field with the sill samples trending into the alkaline arc field (Hollocher et al. 2012)

${ }^{208} \mathrm{~Pb},{ }^{232} \mathrm{Th},{ }^{235} \mathrm{U}$, and ${ }^{238} \mathrm{U}$. The intensities of ${ }^{238} \mathrm{U}$ were left unchanged if measured in a counting mode and recalculated from ${ }^{235} \mathrm{U}$ intensities if the ${ }^{238} \mathrm{U}$ was acquired in analogue mode. Data reduction was then carried out off-line using the Iolite data reduction package, version 3.4 with Visual Age utility (Petrus and Kamber 2012). No ${ }^{204} \mathrm{~Pb}$ (common lead) correction was applied to the data due to the high $\mathrm{Hg}$ contamination of the commercially available He carrier gas, which precludes accurate correction of the interfering ${ }^{204} \mathrm{Hg}$ on the very small signal of ${ }^{204} \mathrm{~Pb}$. Primary concentrations of common $\mathrm{Pb}$ in zircon are considered very low and were controlled by observing the ${ }^{206} \mathrm{~Pb}$ (radiogenic) $/{ }^{204} \mathrm{~Pb}$ ratio. Residual elemental fractionation and instrumental mass bias were corrected by normalization to the natural zircon reference material Plešovice (Sláma et al. 2008; Online Resource 3). The U-Pb isotope data are presented in Online Resource 3 and the CL images in Figs. 9 and 11. Age calculations and data plotting were done with Isoplot 4.15 (Ludwig 2009).

\section{${ }^{40} \mathrm{Ar} /{ }^{39} \mathrm{Ar}$ step-heating dating}

Metagabbro sample Ba-27 was crushed, cleaned with water and sieved to a $250-500 \mu \mathrm{m}$ size fraction and then washed in an ultrasonic bath to remove fines. After drying, 100 hornblende grains were handpicked under a stereo-microscope (up to 40 times magnification). Sample Ba-27 was selected for ${ }^{40} \mathrm{Ar} /{ }^{39} \mathrm{Ar}$ dating because of its higher, amphibolite-facies grade of metamorphism that contrasts with that of the surrounding rocks of the $\mathrm{BNC}$, suggesting that it could be a fragment of the basement. The picked hornblende grains were irradiated with fast neutrons for four hours in August 2017 at the CLICIT (Cadmium-Lined In-Core Irradiation Tube) facility of the Oregon State TRIGA Reactor (OSTR) of Oregon State University, USA. The international age standard Fish Canyon Tuff sanidine, which was prepared by the Geological Survey of Japan (FC-3, 27.5 Ma; Uto et al. 1997; Ishizuka 1998), was irradiated together with the samples. To correct for the interference of Ar isotopes produced by the reactions of $\mathrm{Ca}$ and $\mathrm{K}$ in the samples, additional crystals of $\mathrm{K}_{2} \mathrm{SO}_{4}$ and $\mathrm{CaF}_{2}$ were co-irradiated with the unknowns.

${ }^{40} \mathrm{Ar} /{ }^{39} \mathrm{Ar}$ dating was done at the ${ }^{40} \mathrm{Ar} /{ }^{39} \mathrm{Ar}$ Geochronology Laboratory of the Institute of Geosciences of the University of Potsdam. Sample gases were released from amphibole by stepwise heating for $30 \mathrm{~s}$ by increasing the laser power of a New Wave Research Dual Wave $\mathrm{CO}_{2}$ infrared laser (wavelength $10.6 \mu \mathrm{m}$, maximum output $50 \mathrm{~W}$ ) with $1450 \mu \mathrm{m}$ beam diameter for each heating step. After each heating step, the released sample-gas was purified for $10 \mathrm{~min}$ in the gas purification line with SAES Zr-Al getter pumps (one at room temperature and the other at $400^{\circ} \mathrm{C}$ ) and a cold trap kept at $-90^{\circ} \mathrm{C}$ with an electric immersion cooler, close to the freezing temperature of ethanol. After purification, Ar gas was introduced into the mass spectrometer and analyzed. The mass spectrometer was operated using the peakjumping method in a static mode in which the intensities of Ar isotope beams were measured with a single electron multiplier for a total of $900 \mathrm{~s}$. Zr-Al getter pumps in the mass spectrometer are running continuously during analysis to maintain the purity of Ar and to assure a constant low level of the residual active gases.

The natural isotope ratios of $\mathrm{Ar}$ and $\mathrm{K}$ and decay constants of ${ }^{40} \mathrm{~K}$ used for ${ }^{40} \mathrm{Ar} /{ }^{39} \mathrm{Ar}$ age calculation are adopted from Steiger and Jäger (1977). Data reduction, age calculations and diagram construction were done with the "MassSpec" software made by Dr. Alan Deino, Berkeley Geochronology Center, USA. The argon isotope data are presented in Online Resource 4.

\section{Results}

\section{Geochemistry}

\section{Major elements}

The major and trace elements data are plotted using the GCDkit (version 4.0) software of Janoušek et al. (2014).

In the total alkalis vs. silica (TAS) diagram (Le Bas et al. 1986), all least-altered samples define a slightly convex trend ranging from basaltic to rhyolitic compositions and generally following a subalkaline trend (Fig. 6a), sills have high $\mathrm{SiO}_{2}$ and $\mathrm{Na}_{2} \mathrm{O}+\mathrm{K}_{2} \mathrm{O}$ contents. Ignimbrites vary from dacite to rhyolite, tuffs from andesite to dacite, and lava samples vary from trachyte to andesite. Compared to least-altered and fresh samples, altered samples (containing secondary 
minerals such as sericitic white mica, chlorite etc.) have lower $\mathrm{Na}_{2} \mathrm{O}+\mathrm{K}_{2} \mathrm{O}$ contents (purple crosses in Fig. 6a).
This probably reflects mobility of $\mathrm{Na}, \mathrm{K}$ and $\mathrm{Si}$ during alteration processes. Signs of alteration in other ignimbrite
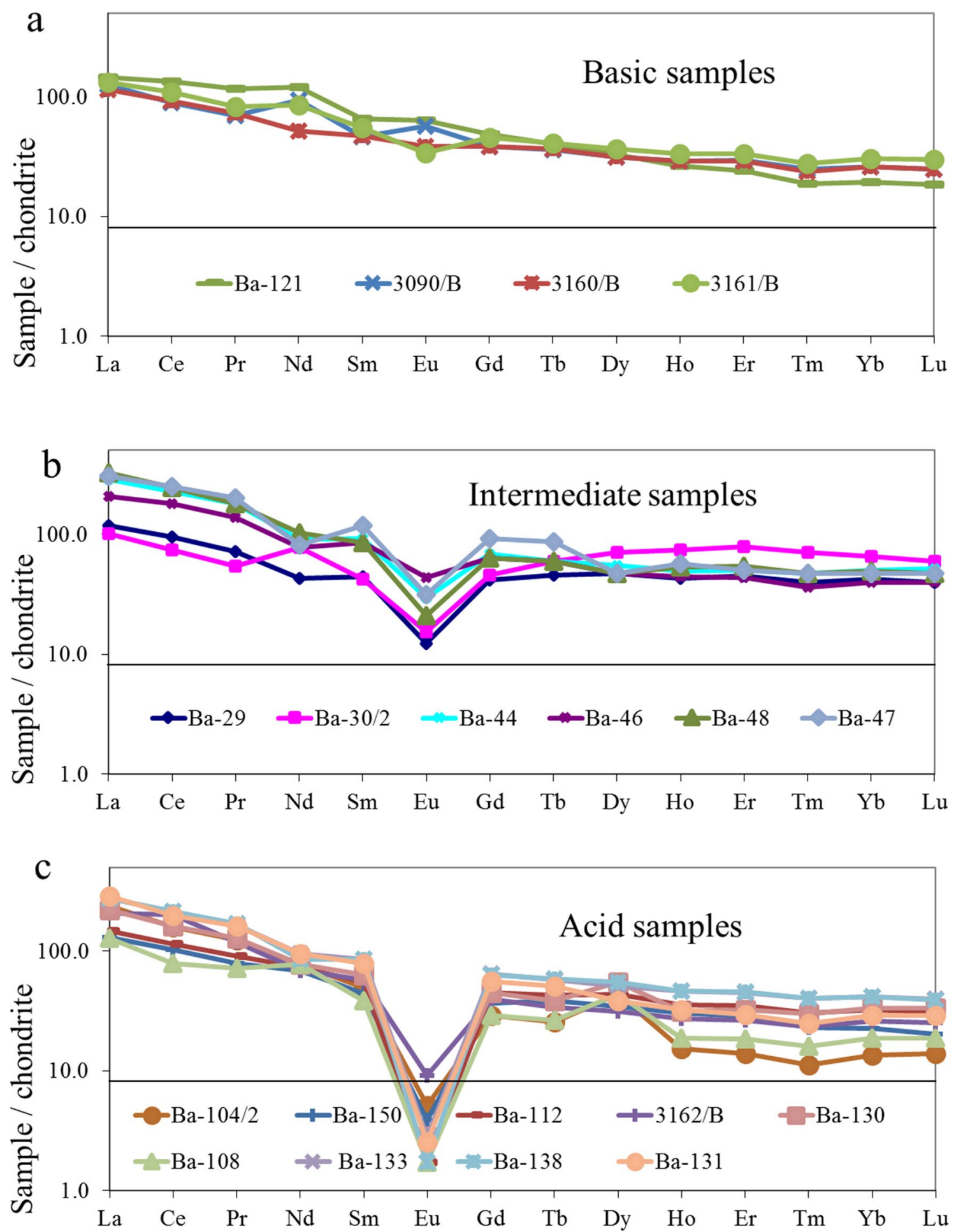

Fig. 7 Chondrite normalized whole rock REE abundances of basic (a), intermediate (b), and (c) acid samples of the BNC, using the $\mathrm{C1}$ normalization values of McDonough and Sun (1995). Basic samples lack Eu negative anomalies or developed very small ones (a), which appear and increase with increasing $\mathrm{SiO}_{2}$ contents (b, c), pointing to plagioclase fractionation. Intermediate samples: dacites and andesites. Basic samples: basalts and basaltic andesites. Acid samples: rhyolite-dacite lavas 
and porphyric rhyolite samples may explain the scatter in $\mathrm{Na}_{2} \mathrm{O}+\mathrm{K}_{2} \mathrm{O}$ contents within the rhyolite field (Fig. 6a).

Only samples with LOI values (Kyrgyzstan analyses) and $\mathrm{CO}_{2}+\mathrm{H}_{2} \mathrm{O}$ abundances (Potsdam analyses) less than 0.75 $\mathrm{Wt} \%$ and $\mathrm{SiO}_{2}$ contents between 48 and $75 \mathrm{Wt} \%$ were plotted in the $\mathrm{K}_{2} \mathrm{O}$ vs. $\mathrm{SiO}_{2}$ diagram of Peccerillo and Taylor (1976) (Fig. 6c), thus excluding the basalt samples that have $\mathrm{SiO}_{2} \leq 45 \mathrm{Wt} \%$. Lava samples define a trend from the calcalkaline to high-potassium calc-alkaline fields (blue squares in Fig. 6c).

In the AFM diagram of Irvine and Baragar (1971), all samples define a calc-alkaline trend, as in the TAS diagram (Fig. 6a). Three least-fractionated lava samples have high $\mathrm{MgO}$ (Fig. 7d). AFM diagram showing that most of the samples form a calc-alkaline series, but that some altered samples plot in the tholeiite field ( $\mathrm{MgO}$ from 13 to $22 \mathrm{Wt} \%$ ) and in the lower right corner (blue squares, samples 2008, $3024,3024 / 1$ ). Sills have high $\mathrm{Al}_{2} \mathrm{O}_{3}$ concentrations and the more fractionated samples (samples 2051, 2059, 3150A, 2051/2 2079, 2070/2) have similar $\mathrm{FeO}$ and $\mathrm{MgO}$ contents and form a cluster, apart from sample 2059 (Fig. 6d; Online Resources 2A and $2 \mathrm{~B}$ ).

The sill samples cluster at the high $\mathrm{SiO}_{2}$ end of the trend and have variable $\mathrm{Na}_{2} \mathrm{O}+\mathrm{K}_{2} \mathrm{O}$ contents (Fig. 6c), which probably reflect varying modal amounts of alkali feldspar phenocrysts. Lava samples plot in the calc-alkaline field and those with higher $\mathrm{SiO}_{2}$ contents in the high-K calc-alkaline field. Only porphyric rhyolite sill samples with 74 to $76 \mathrm{Wt} \%$ $\mathrm{SiO}_{2}$ were plotted in the aluminum saturation diagram of Maniar and Piccoli (1989), excluding samples with high volatile or LOI values of $>0.77 \mathrm{Wt} \%$ (Online Resources $2 \mathrm{~A}$ and $2 \mathrm{~B}$ ). Compositions of these 17 sill samples vary between metaluminous and peraluminous, with many analyses clustering in the I-type granite field (Fig. 6e).

\section{Trace and rare earth elements}

In the $\mathrm{Nb} / \mathrm{Y}$ vs. $\mathrm{Zr} / \mathrm{Ti}$ diagram of Pearce (1996), the samples belong to the subalkaline series and define a basic to acid trend (Fig. 6b). Specifically, lavas show a continuous trend from basic to acid compositions, ignimbrites and tuffs have intermediate compositions, and rhyolite sills are acid and plot close to the alkaline rhyolite field boundary.

The $\mathrm{Nb} / \mathrm{La}$ vs $\mathrm{La} / \mathrm{Yb}$ diagram (Fig. 6f) shows that most samples of the Big Naryn Complex plot in the continental arc field with $\mathrm{Nb} / \mathrm{La}$ varying between 0.3 and 0.7 , and $\mathrm{La} /$ $\mathrm{Yb}$ between from 4 and 35. Most of the lava samples have similar $\mathrm{Nb} / \mathrm{L}$ a values of $0.3-0.7$ and similar $\mathrm{La} / \mathrm{Yb}$ of $20-35$; ignimbrites and tuffs have lower $\mathrm{La} / \mathrm{Yb}$ of 4-20 (Fig. 6f). The sill samples have much higher $\mathrm{La} / \mathrm{Yb}$ values up to 33 and trend towards the alkaline arc field (Fig. 6f).

Chondrite-normalized REE diagrams for basic to acid samples show similar patterns with Eu negative anomalies that increase from basic to acid rocks (Fig. 7a-c). The patterns for the basic rocks are relatively flat from Ho to $\mathrm{Lu}$ and show light REE (LREE) enrichment $\left(\mathrm{La}_{\mathrm{N}} / \mathrm{Sm}_{\mathrm{N}}=2.2-4.76\right.$ and $\mathrm{La}_{\mathrm{N}} / \mathrm{Lu}_{\mathrm{N}}=1.71-11.15$, Fig. 7a). Middle to heavy REE ratios for the basalt samples are low $\left(\mathrm{Sm}_{\mathrm{N} /} \mathrm{Lu}_{\mathrm{N}}=0.71-3.53\right)$ and do not support the presence of residual garnet in the source during parent melt generation. Eu anomalies $(\mathrm{Eu} /$ $\mathrm{Eu}^{*}=\mathrm{Eu}_{\mathrm{N}} / \mathrm{sqrt}\left(\mathrm{Sm}_{\mathrm{N}} * \mathrm{Gd}_{\mathrm{N}}\right)$ increase from 0.04 for one basic sample (Fig. 7a) to 0.72 for the acid samples (Fig. 7c), and clearly developed in samples with $\mathrm{SiO}_{2}$ between 55 and 77 $\mathrm{Wt} \%$. Eu is depleted relative to the other REE, which can be explained by fractional removal of plagioclase.

The primitive mantle normalized multi-trace element diagrams for all samples show relatively large variations of trace element abundances from basic to felsic samples (Fig. 8a-c). The basic samples are OIB-like (Fig. 8a) and their $\mathrm{Ti}, \mathrm{Nb}, \mathrm{Zr}$ and LREE concentrations are slightly elevated and lie between those of N-MORB and OIB. Nb- and Ti-negative anomalies develop in more fractionated samples of intermediate to acid compositions (Fig. 8b, c) and $\mathrm{P}$ negative anomalies develop first in samples of intermediate composition (Fig. 8b).

\section{$\mathrm{U}-\mathrm{Pb}$ zircon dating results}

\section{Rhyolite lava Ba-150}

Zircon dating of rhyolite lava Ba-150 resulted in 24 spot analyses. In CL images, yellow circles denote the beam size and are labeled with analysis number followed by spot age (e.g. Ba_150_207: 735 \pm 10 Ma in Fig. 9, top left).

Zircons from Ba-150 vary from euhedral to broken euhedral crystals and are idiomorphic with rounded prismatic habits with oscillatory, magmatic-type zoning (Fig. 9). Some of the dated grains are present only as crystal fragments and breakage must have occurred during sample crushing. The average size of the analyzed zircons varies between 450 and $550 \mu \mathrm{m}$, while zircon grains Ba-150_217 and Ba-150_233 are larger than $650 \mu \mathrm{m}$.

The 24 zircon analyses of sample Ba-150 show a relatively narrow ${ }^{206} \mathrm{~Pb} /{ }^{238} \mathrm{U}$ age range between 712 and 732 Ma with a concordance of 95 to $101 \%$ (Fig. 10; Online Resource 3). From this age cluster, a pooled or average age of $726.1 \pm 2.2 \mathrm{Ma}$ is calculated. This is interpreted to give the age of crystallization of rhyolite lava Ba-150, and thus to date the volcanism of the Lower Member of the Big Naryn Complex.

\section{Porphyric rhyolite sill Ba-133}

Zircon dating of sample Ba-133 resulted in 40 spot analyses. The zircons vary in size from 450 to $950 \mu \mathrm{m}$ and in shape from euhedral to subhedral, with many being broken 
Fig. 8 Primitive mantle normalized multi-element diagrams. BNC samples are subdivided into those of basic, intermediate and acid composition. The normalization values are from McDonough and Sun (1995). a Basic samples (basalt and basaltic andesite) show flat patterns with small $\mathrm{Nb}$ and Ti anomalies. b Intermediate samples (andesites and andesitic dacites) show well-developed $\mathrm{Nb}, \mathrm{Ti}$ and $\mathrm{Eu}$ anomalies. Some samples show a $\mathrm{P}$ negative anomaly. c Most acid samples (ignimbrites and rhyolite sills) have prominent $\mathrm{Nb}$ and Ti negative anomalies. Especially the rhyolite sill samples show clear $\mathrm{P}$ and Eu negative anomalies
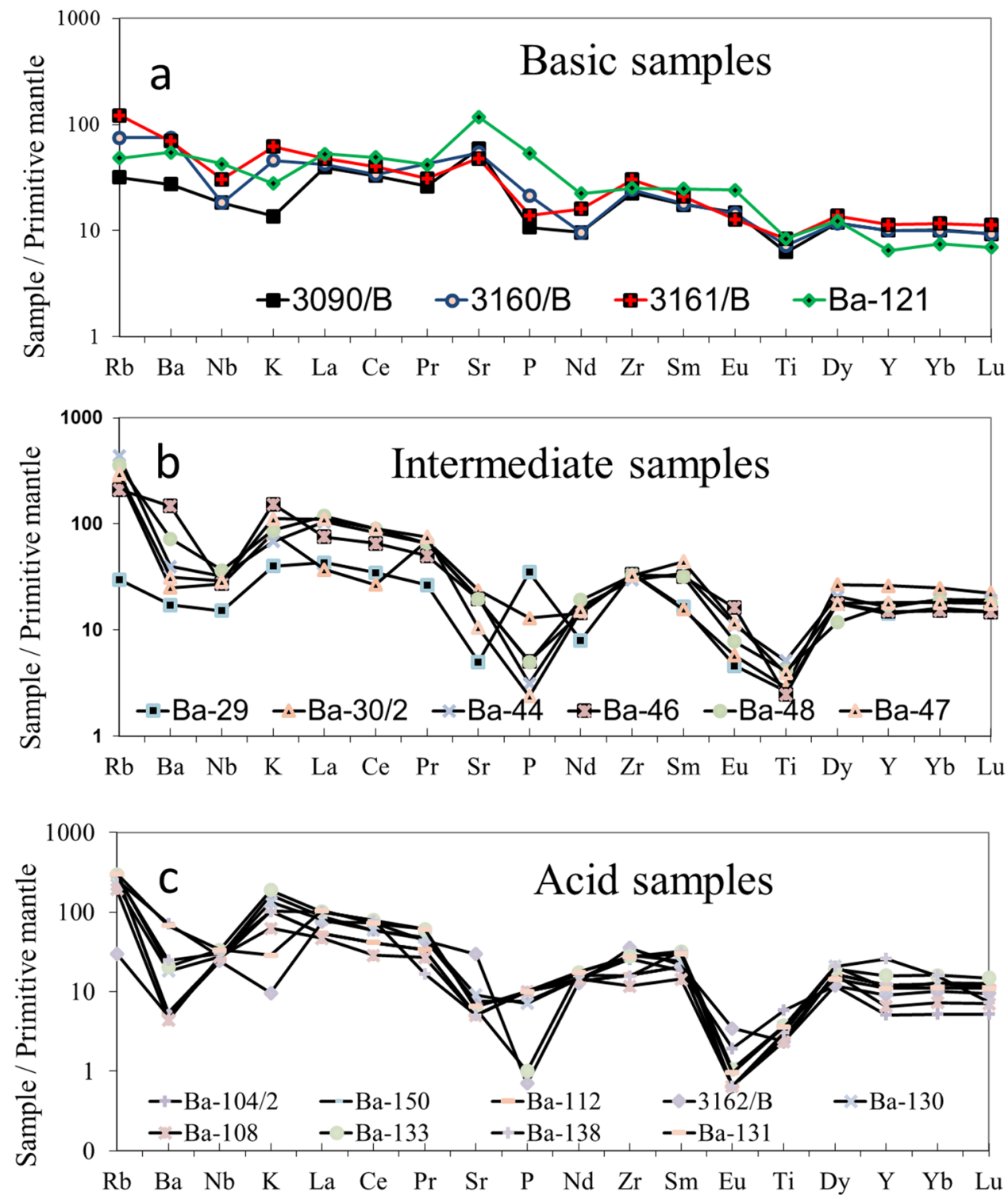

probably due to sample crushing. Euhedral grains are rather rare compared to subhedral ones. Zoning, cores and rims are easily recognizable. Zircon grains with sizes close to $450 \mu \mathrm{m}$ are idiomorphic with rounded prismatic habits (such as Ba-133_298,_296). Grains with sizes close to $950 \mu \mathrm{m}$ are rounded and have internal structures with cores and zoned rims (such as Ba-133_250,_258) that can be distinguished by their different $\mathrm{CL}$ intensities (dark grey-to-black cores, light grey-to-grey rims, Fig. 11).

Sill sample Ba-133 yielded a large spread of zircon ages that, in addition, are slightly more discordant than those of Ba-150 (Fig. 12a). For this reason, 84 to $116 \%$ concordant analyses were used for age calculations. Of the 40 analyses, 16 are from the outer rims of zircon crystals and yielded the youngest ${ }^{206} \mathrm{~Pb} /{ }^{238} \mathrm{U}$ ages in the range $714 \pm 10$ to $741 \pm 11 \mathrm{Ma}$. This spread in ages is too large to allow a pooled (Concordia) age to be calculated and instead we prefer the $720.3 \pm 6.5$ Ma weighted mean of the ${ }^{206} \mathrm{~Pb} /{ }^{238} \mathrm{U}$ ages (Fig. 12b). Six concordant analyses of inner rims (green in Fig. 12a) give ages between $791 \pm 14$ and $849 \pm 16 \mathrm{Ma}$, with a pooled age of $815 \pm 4 \mathrm{Ma}$. The $720.3 \pm 6.5 \mathrm{Ma}$ youngest ${ }^{206} \mathrm{~Pb} /{ }^{238} \mathrm{U}$ age average for the outer rims is interpreted as the crystallization age of the sill, although some spots overlap inner zones. One zircon yielded two ages, a Neoarchean ${ }^{207} \mathrm{~Pb} /{ }^{206} \mathrm{~Pb}$ age for core BA133_249 $(2628 \pm 24 \mathrm{Ma})$ and a Neoproterozoic ${ }^{206} \mathrm{~Pb} /{ }^{238} \mathrm{U}$ age for rim BA133_250 (797 $\pm 13 \mathrm{Ma}$; Online Resource 3).

Zircon core analyses yielded much older ages, which can be divided into two broad groups marked in red and blue in Fig. 12a. Cores marked with blue circles (such as Ba-133_249, _257) yielded the oldest ${ }^{207} \mathrm{~Pb} /{ }^{206} \mathrm{~Pb}$ ages of $2628 \pm 24,2644 \pm 22 \mathrm{Ma}, 2119 \pm 35 \mathrm{Ma}$ and $2329 \pm 29 \mathrm{Ma}$. 


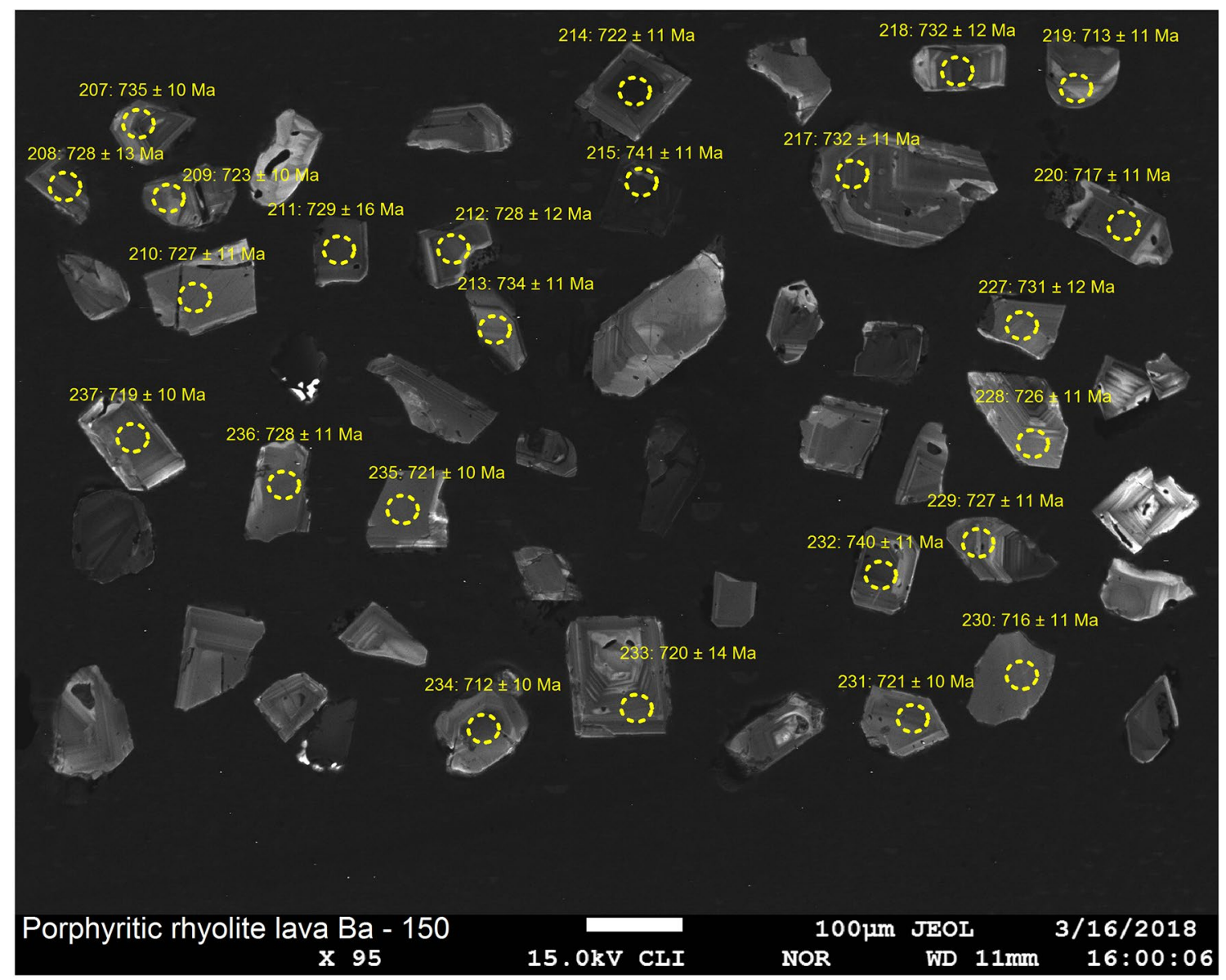

Fig. 9 Cathodoluminescence images of mounted and polished zircons from Lower Member rhyolite lava Ba-150. Circles mark the spots where laser-ablation analysis was performed and denote the beam size. The spots are labeled are with analysis number and $\mathrm{spot}{ }^{206} \mathrm{~Pb} /{ }^{238} \mathrm{U}$ age

In addition, metamict cracks are present in zircon core of sample Ba-133_257 (Fig. 12a). Cores marked in red (e.g. Ba-133_294,_295; Fig. 12a) have younger ${ }^{207} \mathrm{~Pb} /{ }^{206} \mathrm{~Pb}$ ages between $1551 \pm 30 \mathrm{Ma}$ and $1811 \pm 33-2030 \pm 28 \mathrm{Ma}$ and, in addition, are slightly more discordant (up to $20 \%$ ) compared to the older cores marked in blue (Fig. 12a). The latter are clearly of xenocrystal origin and must have been inherited from much older basement material that was partly assimilated by the parent melt of porphyric rhyolite sill Ba-133.

\section{${ }^{40} \mathrm{Ar} /{ }^{39} \mathrm{Ar}$ amphibole step-heating dating results}

Amphibole from Kuilyu Complex metagabbro Ba-27 found below and in tectonic contact with the Lower Member of the BNC yielded a plateau age of $1751 \pm 7$ Ma for steps 4 to 6 of nine gas fractions. The age spectrum is shown in Fig. 13 and the analytical data are listed in Online Resource 4, where the data are presented at 1 sigma levels of analytical uncertainty, whereas apparent ages in the age spectrum are shown at 2 sigma level. Apparent ages for steps 1 to 3 decrease from 2300 to $1515 \mathrm{Ma}$, and the last 3 steps have different apparent ages of 1560, 1712 and $1794 \mathrm{Ma}$. The three gas fractions 4, 5 and 6 have similar $\mathrm{Ca} / \mathrm{K}$ ratios (resp. 6.3, 8.6 and 7.1) and comprise $65 \%$ of the ${ }^{39} \mathrm{Ar}$ released, allowing a $1751 \pm 7 \mathrm{Ma}$ plateau age to be calculated (Fig. 13). The plateau definition is from Fleck et al. (1977) and McDougall and Harrison (1999).

\section{Discussion}

\section{Stratigraphy and petrography}

The nine detailed cross sections (Fig. 2; Online Resource 1) and the stratigraphic columns (Fig. 3) show that the BNC is a folded, thrusted and faulted, and at least $2 \mathrm{~km}$ thick sequence of predominantly felsic volcanic rocks and sills, and also contains petrogenetically unrelated, older and younger material.

The Lower Member of the BNC is up to c. $1100 \mathrm{~m}$ thick and dominantly made up of rhyolite to dacite lavas, which are interlayered with tuffs and tuff-derived sediments, and 
Fig. 10 Concordia diagram for 24 concordant zircons from Lower Member rhyolite lava Ba-150 that yield a $726.1 \pm 2.2$ Ma pooled age

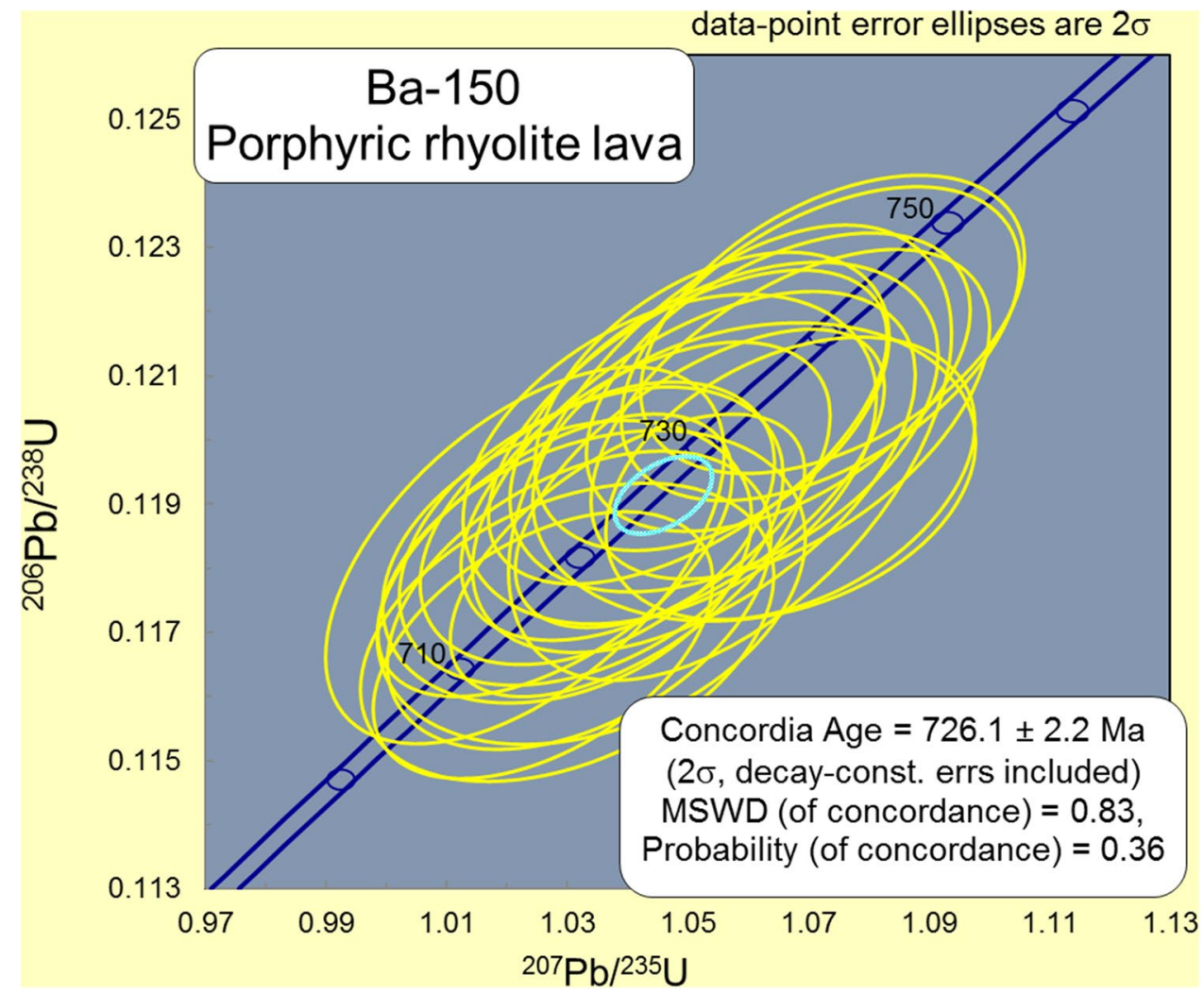

locally with minor basalts. The small amounts $(<10 \%)$ of small quartz and feldspar phenocrysts in the rhyolitedacite lavas indicate that a short, late-stage fractionation of the magma chamber was quickly followed by eruption of mainly lavas with subordinate pyroclastic activity. The large amount of rhyolitic to dacitic ignimbrite in the $>900 \mathrm{~m}$ thick Upper Member illustrates that pyroclastic activity was here more prominent compared to the Lower Member. Altered fiamme and shards in the ignimbrites may be former pumice and glass bubble wall fragments, respectively. The eutaxitic textures resemble flow banding ("rheomorphic" textures), but can also be the result of post-eruption compaction. Alteration and the state of texture preservation do not allow distinguishing between origins as welded or non-welded ignimbrites. The rhyolite sills have margins that are aphyric or contain only a few, small quartz, alkali-feldspar and rare plagioclase phenocrysts. The centers of the sills are porphyric and contain up to $20 \mathrm{vol} \%$ phenocrysts of mainly alkali feldspar of several generations. Such an accumulation of phenocrysts in the center is probably due to subhorizontal flow differentiation during sill intrusion. The thin, clinopyroxene phenocryst-bearing basalts in the lower parts of the Lower Member (see cross section Egizkol-1; Online Resource 1) must represent mantle-derived and much less fractionated melt batches that originated from greater depths or from a separate magma chamber. The presence of amygdales, now filled with secondary minerals, suggests that the basaltic magma contained enough gas to form vesicles during ascent and eruption.

\section{Major and trace element geochemistry}

The Lower Member is basaltic to rhyolitic in composition and the Upper Member andesitic to rhyolitic-dacitic, and all lava samples define a continuous subalkaline trend from basic to acid compositions, indicating a fractionation sequence, as do selected trace elements. Ignimbrites and tuffs have mainly intermediate compositions and the sills are acid and have higher $\mathrm{K}_{2} \mathrm{O}$ and $\mathrm{SiO}_{2}$ contents that are higher than those of the rhyolite lavas (Fig. 6c). This may indicate that they originated from different sources, or reflect contamination of parent magma with crustal material in a magma chamber. Alternatively, the higher $\mathrm{K}_{2} \mathrm{O}$ and $\mathrm{SiO}_{2}$ contents may be due to feldspar phenocryst enrichment in the central parts through flow differentiation during emplacement, as seen in the field. The metaluminous to peraluminous sills correspond to I-type, i.e. subductionrelated granitoids. Both sills and volcanic rocks plot in the continental arc field.

The basic samples are enriched in LREE and Eu anomalies are absent or very small (Fig. 7a-c), which agrees with the absence of plagioclase phenocrysts in the basalts. REE concentrations and the degree of LREE enrichment increase 


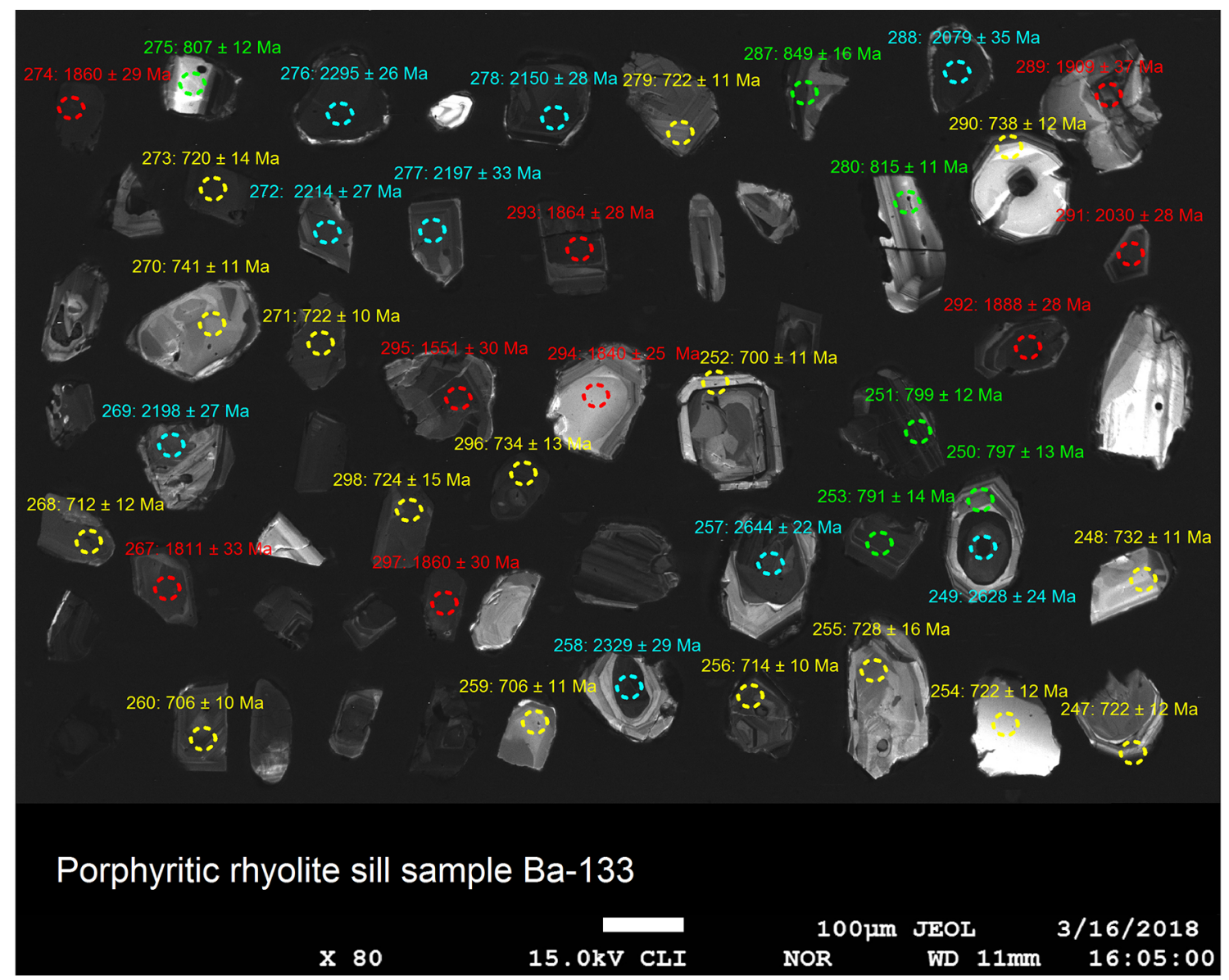

Fig. 11 Cathodoluminescence images of dated zircons from porphyric rhyolite sill sample Ba-133. The spots where laser-ablation analyses were performed are indicated by circles. The different color-coding shows the age variation of rim and cores (for the color image we refer to the online version of this paper). ${ }^{206} \mathrm{~Pb} /{ }^{238} \mathrm{U}$ ages are shown for zircons younger than $1 \mathrm{Ga}$ and ${ }^{207} \mathrm{~Pb} /{ }^{206} \mathrm{~Pb}$ ages for

from basic to acid samples, and so does the magnitude of the Eu negative anomaly. The increasing Eu anomaly is most likely the result of feldspar removal (especially plagioclase) from the parent magma by fractionation processes, which is supported by the presence of feldspar phenocrysts in most rhyolite-dacite lavas. The multi-element patterns show similarities to OIB, but have $\mathrm{Nb}$ and Ti negative anomalies (Fig. 8a-c). Basic samples lack Ti anomalies, but have weak negative $\mathrm{Nb}$ and $\mathrm{Zr}$ anomalies. From basic to acid samples, the $\mathrm{Nb}$ and $\mathrm{Ti}$ anomalies increase and correlate with increasing $\mathrm{SiO}_{2}$ content, which is typical for volcanic arc systems (e.g. Thirlwall et al. 1994). P negative anomalies in intermediate and acid samples reflect crystallization and removal of apatite (Fig. 8c, d).

The dominance of acid, calc-alkaline compositions and the trace element characteristics suggests formation of the $\mathrm{BNC}$ in a continental volcanic arc setting. Such volcanism is frequently highly explosive, leading to the eruption of zircons older than $1 \mathrm{Ga}$. Blue circles are cores with ages between $2114 \pm 21 \mathrm{Ma}$ and $2598 \pm 28 \mathrm{Ma}$; red circles are cores with ages between $1541 \pm 18$ to $1804 \pm 20 \mathrm{Ma}$, green circles are inner rims with ages between $791 \pm 14 \mathrm{Ma}$ and $849 \pm 12 \mathrm{Ma}$, and yellow circles are outer rims with ages between $714 \pm 10$ and $744 \pm 14 \mathrm{Ma}$

tuffs and ignimbrites, as seen in the BNC. The presence of subalkaline to high-K calk alkaline volcanic rocks may be explained by fractionation and eruption in continental crust of increased thickness, leading to the elevated $\mathrm{K}_{2} \mathrm{O}$ concentrations of the most fractionated samples.

\section{${ }^{40} \mathrm{Ar} /{ }^{39} \mathrm{Ar}$ age and $\mathrm{U}-\mathrm{Pb}$ ages}

${ }^{40} \mathrm{Ar} /{ }^{39} \mathrm{Ar}$ step-heating dating of amphibole from amphibolite-facies metagabbro Ba-27 yielded a ca.1.75 Ga plateau age, which we interpret as the amphibole cooling age following amphibolite-facies metamorphism of the Kuilyu Complex units in Paleoproterozoic times.

$\mathrm{U}-\mathrm{Pb}$ zircon ages of Lower Member rhyolite lava sample Ba-150 are all concordant and cluster, yielding a pooled age of $726.1 \pm 2.2 \mathrm{Ma}$, which is interpreted as the crystallization age of the lavas, and thus to date the volcanic activity of the Lower Member of the Big Naryn Complex to the late 


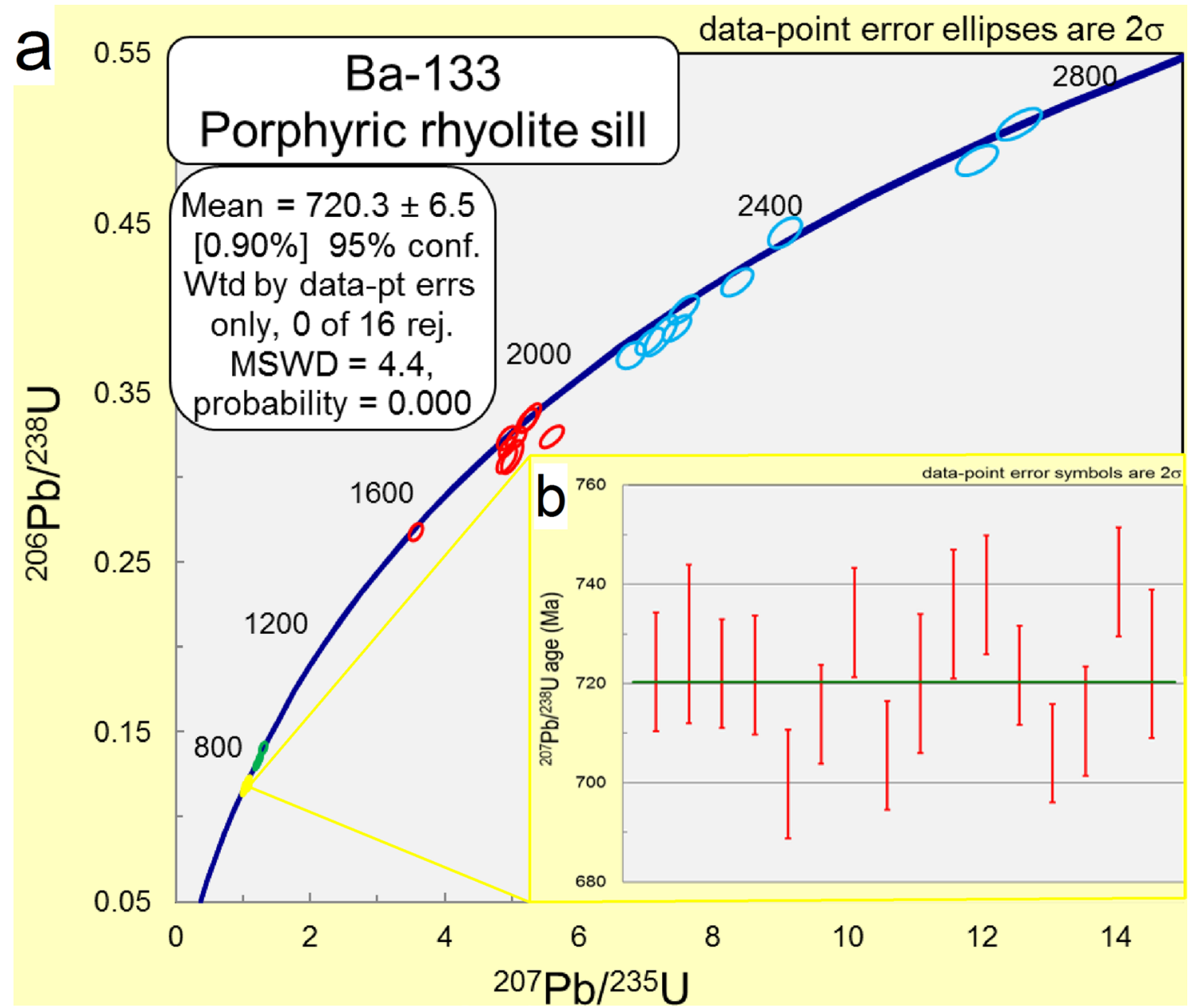

Fig. 12 a Concordia diagram for 40 dated zircons from porphyric rhyolite sill sample Ba-133 showing a wide age spectrum and age clusters. Color coding as in Fig. 11; for the color image we refer to the online version of this paper. b Sixteen analyses of zircon outer

Neoproterozoic (late Tonian). No inherited zircon grains were found in this sample.

Zircons from rhyolite sill sample Ba-133 show complex internal textures (cores, inner and outer rims) that yield a wide spectrum of $\mathrm{U}-\mathrm{Pb}$ ages, substantiating the presence of zircons of different generations. Sixteen spot analyses of zircon outer rims pool around $720.3 \pm 6.5 \mathrm{Ma}$ and this youngest ${ }^{206} \mathrm{~Pb} /{ }^{238} \mathrm{U}$ age average is interpreted to date sill intrusion and crystallization. The oldest cores have Neoarchean (2.63 and $2.64 \mathrm{Ga}$ ) to Paleoproterozoic $(2.12-2.33 \mathrm{Ga}){ }^{207} \mathrm{~Pb} /{ }^{206} \mathrm{~Pb}$ ages, while younger cores show slightly discordant $1.55 \mathrm{Ga}$ and $1.81-2.03 \mathrm{Ga}$ Paleo- to Mesoproterozoic ${ }^{207} \mathrm{~Pb} /{ }^{206} \mathrm{~Pb}$ ages. These old ages must represent xenocrysts derived from recycled crustal material or assimilated crustal contaminants, which were later overgrown by younger magmatic rims. To a certain degree, the core ages must reflect the age spectrum of basement lithologies in which the parent melt rims have ${ }^{206} \mathrm{~Pb} /{ }^{238} \mathrm{U}$ ages in the range $714 \pm 10 \mathrm{Ma}$ to $741 \pm 11 \mathrm{Ma}$, for which a youngest $720.3 \pm 6.5 \mathrm{Ma}$ weighted mean of the ${ }^{206} \mathrm{~Pb} /{ }^{238} \mathrm{U}$ ages can be calculated (horizontal line)

fractionated or passed through. Six concordant analyses of zircon inner rims are older than the outer rim ages and vary between ca. $791 \pm 14 \mathrm{Ma}$ and $849 \pm 16 \mathrm{Ma}\left(^{238} \mathrm{U} /{ }^{206} \mathrm{~Pb}\right.$ ages $)$. The ca. $60 \mathrm{Ma}$ age spread for inner rims may partly reflect mixed ages due to the laser beam overlapping different zircon parts, but may also reflect contributions from older late Neoproterozoic rocks not yet identified in the study area, but that have been recognized in the Sary-Dzhaz and Akshairak ranges to the east (Glorie et al. 2011; see below).

The youngest age clusters of the Lower Member rhyolitic lava and the sill samples are indistinguishable within analytical uncertainty and show that volcanic activity and sill emplacement occurred in the late Tonian to early Cryogenian around 726-720 Ma. The different zircon age spectra of the two samples indicate that they must represent magma batches derived from different parts of the magma chamber, or from different magma chambers. 


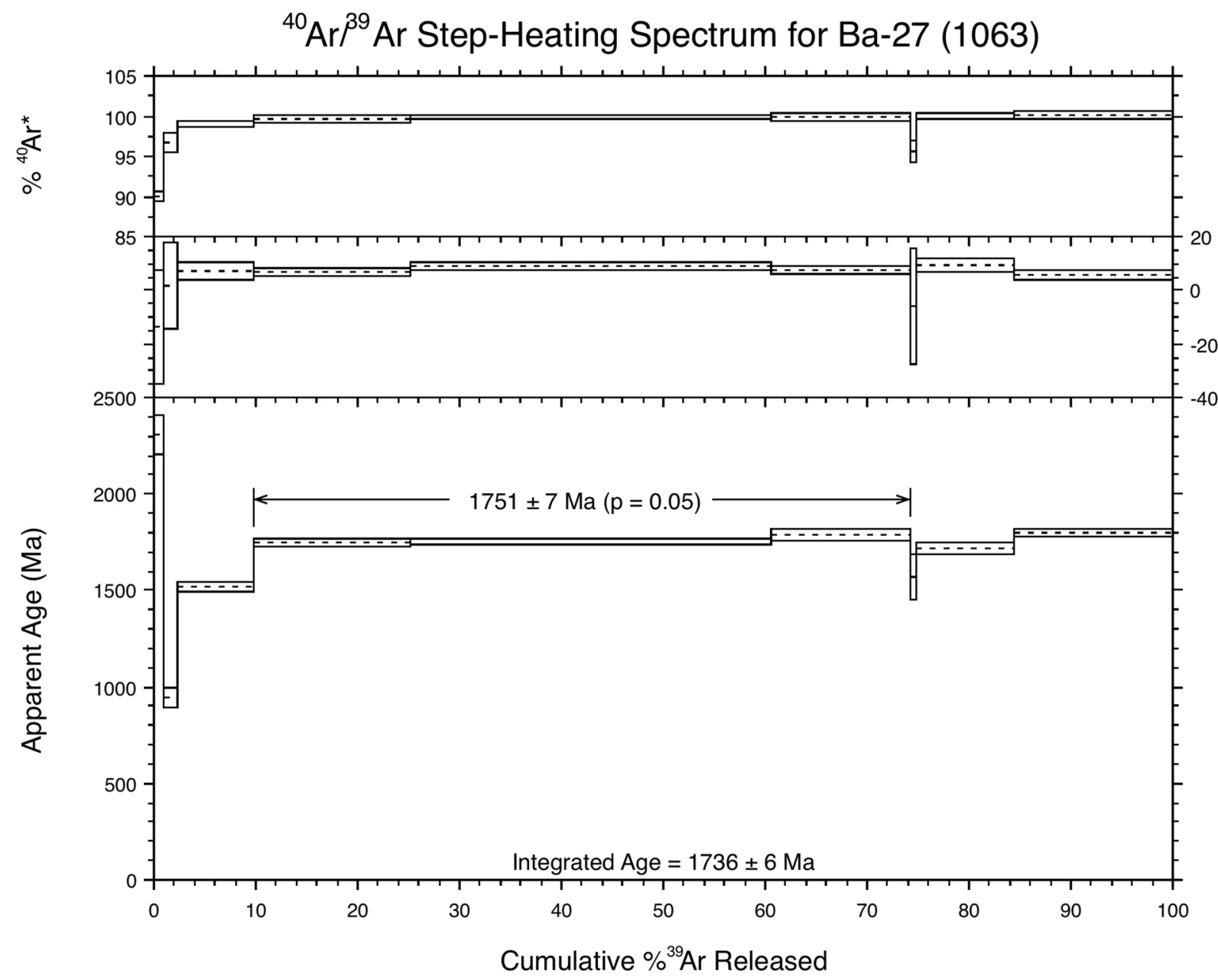

Fig. $13{ }^{40} \mathrm{Ar} /{ }^{39} \mathrm{Ar}$ step-heating gas release spectrum for metamorphic amphibole from metagabbro Ba-27 (Kuilyu Complex). A $1751 \pm 7$ Ma plateau age can be calculated for gas fractions 4,5 and 6 that have similar $\mathrm{Ca} / \mathrm{K}$ ratios and comprise ca. $65 \%$ of the ${ }^{39} \mathrm{Ar}$ released

The zircon cores in Ba-133 represent contaminants derived from crustal material and this contrasts with previous studies than assume that much of the Neoproterozoic crust in the CAOB was derived from subduction-related, but juvenile melts (e.g. Safonova 2017). Glorie et al. (2011) found Paleo- (2500-1850 Ma) and Mesoproterozoic (1200-1000 Ma) inherited zircons in a migmatite and in Neoproterozoic granitoids ( $831 \pm 6 \mathrm{Ma})$ and felsic tuff $(842 \pm 16 \mathrm{Ma})$ of the Middle Tianshan block exposed in the Sary-Dzhaz and Akshairak ranges, ca. $150 \mathrm{~km}$ along strike to the northeast of the BNC. The ca. $791 \pm 14 \mathrm{Ma}$ to $849 \pm 16 \mathrm{Ma}$ ages of inner zircon rims in BNC sill sample Ba-133 partly overlap these 830-840 Ma ages and may stem from related rocks that are not exposed or have not yet been recognized in the Djetim-Too area. Zircons from much older felsic gneisses of the Kuilyu Complex in the Sary-Dzhaz Range yielded Paleoproterozoic, ca. 1.83, 1.85, 1.93, 2.08, 2.32 and $2.33 \mathrm{Ga}{ }^{207} \mathrm{~Pb} /{ }^{206} \mathrm{~Pb}$ mean ages and upper intercept ages (Kröner et al. 2017). Neoarchean zircons appear to be absent in these studies, whereas 2.57-2.62 Ga upper intercept ages for multi-grain zircon fractions are reported by Kiselev (2014, and references therein). Although Neoarchean zircons appear to be absent in the studies of Glorie et al. (2011) and Kröner et al. (2017), and zircons with 1200-1000 Ma ages are lacking in BNC sill sample Ba-133, it is clear that much older crustal material must have made significant contributions to the Neoproterozoic arc rocks of the Djetim-Too, Sary-Dzhaz and Akshairak ranges.

The 726-720 Ma arc-related rocks of the BNC probably represent the youngest part of a long-lived, since 950-900 Ma active margin bordering a continent (Kheraskova et al. 2010). In their model, this continent formed after the break-up of Rodinia at 950-900 Ma and comprised the North China block, parts of the Tianshan block and the basement to the Tarim Basin. Subduction of the so-called Paleoasia ocean beneath these blocks appears to have given way to rifting at 755-690 Ma with attendant alkaline bimodal magmatism and opening of the Sak paleo-ocean (Kheraskova 
et al. 2010; Alexeiev et al. 2019, and references therein). However, the calc-alkaline, predominantly intermediate to acid, and explosive character of the Big Naryn Complex argue against a rift setting at 726-720 Ma in the Djetim-Too area, but instead favor an active continental magmatic arc situated on Kuilyu Complex type crust.

\section{Alteration}

Alteration of BNC lithologies is pervasive but varies in type and intensity, with most samples retaining their primary magmatic textures. The propylitic and sericitic alteration was clearly due to reaction with water-rich fluids that infiltrated permeable volcanic rocks (such as ignimbrites and tuffs). It is clear from the geological map and earlier studies that alteration was controlled by fluid flux along and near later faults, which in the Djetim-Too Range are also associated with local mineralization. In these much younger thrust and fault zones, complete obliteration of primary minerals and textures was accompanied by cleavage formation and reaction of $\mathrm{Ca}$-rich plagioclase to sericite and epidote. Unpublished ${ }^{40} \mathrm{Ar} /{ }^{39} \mathrm{Ar}$ step-heating dating results of altered groundmass and altered feldspar phenocrysts of BNC volcanic rocks and sills clearly indicate that deformation and alteration occurred sometime between the mid-Carboniferous and early Permian (Hegner et al. 2010; Terbishalieva 2018). In the Djamanechky cross-section (Online Resource 1), BNC rocks are tectonically juxtaposed against mid-Carboniferous siliciclastic sediments that are intruded by granite and syenite dykes that, in nearby areas, have yielded early Permian (ca. 295-265 Ma) crystallization ages (Alexeiev et al. 2019). Therefore, northward thrusting, stacking and tectonic intercalation of BNC and basement units must be due to Late Carboniferous to Early Permian closure of an ocean basin and subsequent terrane docking in the South Tianshan (e.g., Biske and Seltmann 2010; Jourdon et al. 2017).

\section{Conclusions}

The Big Naryn Complex exposed in the East Djetim-Too Range of the Kyrgyz Middle Tianshan block is a tectonized, at least $2 \mathrm{~km}$ thick sequence of predominantly felsic to intermediate volcanic rocks intruded by porphyric rhyolite sills. The BNC overlies a Kuilyu Complex basement of greenschist- to amphibolite-facies chlorite-mica schists, metadolerites and metagabbros, and is overlain by glaciogenic clastic sediments of the late Neoproterozoic DjetimToo Formation. Rocks of both the basement and Djetim-Too Formation also occur tectonically intercalated in the BNC, the former mainly in the lower parts of its Lower Member. Figure 14 shows the composite stratigraphic column for the
Eastern Djetim-Too Range with approximate thicknesses of the Lower and Upper members and the geological relations between the Big Naryn Complex, Kuilyu Complex and Djetim-Too Formation. The dated samples are shown in their approximate (tectono-) stratigraphic positions.

The BNC comprises two volcanic members and discordant rhyolite sills. Rhyolite-to-dacite lavas containing quartz and alkali feldspar phenocrysts dominate the up to $1100 \mathrm{~m}$ thick Lower Member that also contains interlayered tuffs and tuff-derived sediments, and minor basalts. The at least $900 \mathrm{~m}$ thick Upper Member is dominated by pyroclastic rocks, mainly rhyolitic to dacitic ignimbrites, often with eutaxitic textures and altered glass shards and fiamme. Later porphyric rhyolite sills are concentrated at the top of the Lower Member, and intruded into zones of weakness and along the contact between both members. Many sills have centers that are enriched in alkali feldspar phenocrysts, which is likely to be a result of flow differentiation during magma intrusion.

Volcanic rocks and sills form a basaltic to rhyolitic series of mainly calc-alkaline character; the rhyolite sills and many of the Upper Member ignimbrites have high $\mathrm{SiO}_{2}$ contents. In addition, the rhyolite sills have high-K calc-alkaline, metaluminous-to-peraluminous I-type characteristics. All samples are enriched in LREE and basalts have smooth REE patterns. Eu negative anomalies are prominent in intermediate to acid rocks (including the sills) and increase with increasing silica contents, pointing to plagioclase fractionation. In primitive mantle normalized multi-element diagrams, all BNC samples show Ti negative anomalies suggesting formation in a supra-subduction zone setting.

A Lower Member rhyolite and a sill sample have ca. 726 and $720 \mathrm{Ma} \mathrm{U}-\mathrm{Pb}$ zircon crystallization ages that overlap within analytical uncertainty. Most of the BNC magmatism therefore occurred within a short time span in the Neoproterozoic (late Tonian-early Cryogenian). The rhyolite lava lacks older, inherited zircons, while the sill sample contains zircon cores with Neoarchean $(2.63,2.64 \mathrm{Ga})$ ages. Paleoproterozoic (2.33 to $1.81 \mathrm{Ga}$ ) and Mesoproterozoic $(1.55 \mathrm{Ga})$ ages, and zircon inner rims have a ca. 815 Ma pooled age. The Neoarchean to Mesoproterozoic zircon components must have been inherited from basement rocks, whereas the ca. 815 Ma old zircons must originate from Neoproterozoic basement rocks that are older than the BNC, but have not yet been identified in the East Djetim-Too Range. ${ }^{40} \mathrm{Ar} /{ }^{39} \mathrm{Ar}$ step-heating dating of amphibole from a Kuilyu Complex metagabbro yielded a ca. $1.75 \mathrm{Ga}$ plateau age, which is interpreted as the cooling age following metamorphism of basement in Paleoproterozoic times.

The large amount of pyroclastic rocks, especially in the Upper Member, in combination with major and trace element compositions, the presence of Neoarchean to Neoproterozoic inherited zircons and a depositional basement of metamorphic rocks (Kuilyu Complex) point to the formation 


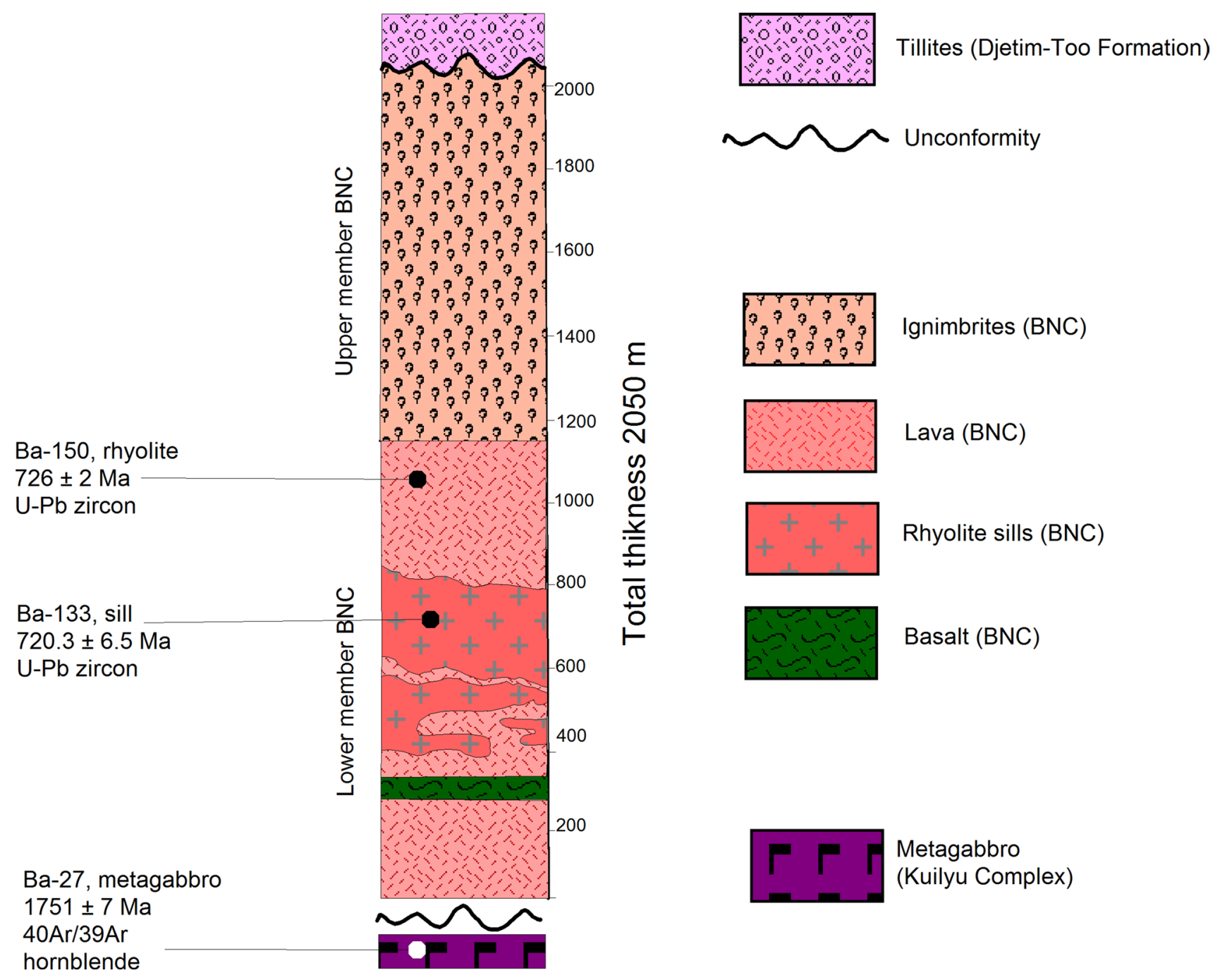

Fig. 14 Composite stratigraphic column for the Eastern Djetim-Too Range showing approximate thicknesses and relations between the Big Naryn Complex, Kuilyu Complex and Djetim-Too Formation. The dated samples are shown in their approximate stratigraphic positions

of the BNC in a continental magmatic arc setting. Northwards thrusting resulting in tectonic intercalation of basement rocks and widespread alteration likely occurred in late Paleozoic times and was due to terrane accretion and the formation of a fold and thrust belt to the south, in the South Tianshan block.

Acknowledgements This paper is the result of the first author's Master project at the Institute of Geosciences, University of Potsdam. B. Terbishalieva thanks colleagues of the Northern Kyrgyz-Geological Expedition, especially the Pchanskyi Survey department team. She is also grateful to the Institute of Geology, Academy of Science of Kyrgyz Republic for funding her during the three years of studying, and to Prof. R. Djenchuraeva for explaining every detail of Tianshan geology. B. Terbishalieva thanks Christine Fischer for her supervision during laboratory work. Jiří Sláma was supported by the Academy of Sciences of the Czech Republic institutional support to the Institute of Geology, ASCR, RVO 67985831. We thank the reviewers Anonymous and A. von Quadt for their valuable comments that improved the quality of the manuscript.

Author contributions The contributions of all authors are according to the guides of IJES.

Funding Open Access funding enabled and organized by Projekt DEAL. Jiří Sláma was supported by the Academy of Sciences of the Czech Republic institutional support to the Institute of Geology, ASCR, RVO 67985831.

Availability of data and materials All data will be available online as Online Resources/supplements.

\section{Compliance with ethical standards}

Conflict of interest The authors declare no conflict of interest. 
Open Access This article is licensed under a Creative Commons Attribution 4.0 International License, which permits use, sharing, adaptation, distribution and reproduction in any medium or format, as long as you give appropriate credit to the original author(s) and the source, provide a link to the Creative Commons licence, and indicate if changes were made. The images or other third party material in this article are included in the article's Creative Commons licence, unless indicated otherwise in a credit line to the material. If material is not included in the article's Creative Commons licence and your intended use is not permitted by statutory regulation or exceeds the permitted use, you will need to obtain permission directly from the copyright holder. To view a copy of this licence, visit http://creativecommons.org/licenses/by/4.0/.

\section{References}

Alexeiev DV, Ryazantsev AV, Kröner A, Tretyakov AA, Xia X, Liu DY (2011) Geochemical data and zircon ages for rocks in a highpressure belt of Chu-Yili Mountains, southern Kazakhstan: implications for the earliest stages of accretion in Kazakhstan and the Tianshan. J Asian Earth Sci 42:805-820. https://doi.org/10.1016/j. jseaes.2010.09.004

Alexeiev DV, Biske YuS, Djenchuraeva AV, Kröner A, Getman OF (2019) Late Carboniferous (Kasimovian) closure of the South Tianshan Ocean: No Triassic subduction. J Asian Earth Sci 173:54-60. https://doi.org/10.1016/j.jseaes.2019.01.021

Baev DG, Chernov VI, Bashkirov AP (1989) Geological structure and minerals of the Ak-Shyirak (east) Range (sheets K-44-61-G-v,g; K-44-73-A,B,V,G). Report of the Akbel geological survey andexploration activities at a scale 1:50 000 carried out in 1983-1989. Frunze. Archives of the State Geological Agency of the Kyrgyz Republic. (in Russian)

Bakirov AB, Ges MD, Dzhenchuraeva RD, Kiselev VV, Maksumova RA, Mezgin IA, Pak NT, Sabelnikov SE, Sakiev KS (2014) Geodynamics and mineralization of the Tien Shan (Kyrgyzstan). Bishkek, Ilim, 280 pp ISBN 9967124504,9789967124509 (in Russian)

Bazhenov M, Mikolaichuk A (2004) Formation of the structure of Central Asia north of Tibet: synthesis of paleomagnetic and geological data. Geotectonics 5:68-84

Biske YuS, Seltmann R (2010) Paleozoic Tian-Shan as a transitional region between the Rheic and Urals-Turkestan oceans. Gondwana Res 17:602-613. https://doi.org/10.1016/j.gr.2009.11.014

Chumakov NM (2009) Neoproterozoic glacial events in Eurasia. In: Gaucher C, Sial AN, Halverson GP, Frimmel HE (Eds) Neoproterozoic-Cambrian Tectonics, Global Change and Evolution: a focus on southwestern Gondwana. Develop Precambrian Geol 16:389-403. https://doi.org/https://doi.org/10.1016/S0166 $-2635(09) 01627-2$

Chumakov NM (2011) Glacial deposits of the Baykonur Formation, Kazakhstan and Kyrgyzstan. In: Arnaud E, Halverson GP, Shields-Zhou G (eds) The geological record of Neoproterozoic Glaciations. Geol Soc London Mem 36:303-307. https://doi. org/https://doi.org/10.1144/M36.26

Dietrich V, Schwandner F, Vils F (2004) Preparation of glass beads and powder pills for XRF analysis of silicic and calcareous rocks. Institute of mineralogy and petrography, ETH Zurich

Dodonova TA, Goretskaya EN (1972) Intrusive formations of geosyncline stage of development. In: Geology of the USSR. Volume XXV. Kyrgyz SSR. Moskow: Nedra, 1972. Book 2. pp. 54-99 (in Russian)

Dulski P (1994) Interferences of oxide, hydroxide, and chloride analyte species in the determination of rare earth elements in geological samples by inductively coupled plasma-mass spectrometry. J Anal Chem 450:194-204. https://doi.org/10.1007/BF00322470

Fleck RJ, Sutter JF, Elliot DH (1977) Interpretation of discordant ${ }^{40} \mathrm{Ar} /{ }^{39} \mathrm{Ar}$ age-spectra of Mesozoic tholeiites from Antarctica. Geochim Cosmochim Acta 41:15-32. https://doi. org/10.1016/0016-7037(77)90184-3

Glorie S, De Grave J, Buslov MM, Zhimulev FI, Stockli DF, Batalev VY, Izmer A, Van den Haute P, Vanhaecke F, Elburg MA (2011) Tectonic history of the Kyrgyz South Tien Shan (AtbashiInylchek) suture zone: the role of inherited structures during deformation-propagation. Tectonics 30:TC6016. https://doi. org/10.1029/2011TC002949

Hegner E, Klemd R, Kröner A, Corsini M, Alexeiev DV, Iaccheri LM, Zack T, Dulski P, Xia X, Windley BF (2010) Mineral ages and $\mathrm{P}-\mathrm{T}$ conditions of late Paleozoic high-pressure eclogite and provenance of mélange sediments from Atbashi in the South Tianshan Orogen of Kyrgyzstan. Am J Sci 310:916-950. https://doi. org/10.2475/09.2010.07

Hollocher K, Robinson P, Walsh E, Roberts D (2012) Geochemistry of amphibolite-facies volcanics and gabbros of the Storen Nappe in extensions west and southwest of Trondheim, western gneiss region, Norway: a key to correlations and paleotectonic settings. Am J Sci 312:357-416. https://doi.org/10.2475/04.2012.01

Irvine TN, Baragar WRA (1971) A guide to the chemical classification of the common volcanic rocks. Can J Earth Sci 8:523-548. https ://doi.org/10.1139/e71-055

Ishizuka O (1998) Vertical and horizontal variations of the fast neutron flux in a single irradiation capsule and their significance in the laser-heating ${ }^{40} \mathrm{Ar} /{ }^{49} \mathrm{Ar}$ analyses: case study of the hydraulic rabbit facility of the JMTR reactor, Japan. Geochem J 42:244-252

Janoušek V, Farrow CM, Erban V (2014) Interpretation of whole-rock geochemical data in igneous geochemistry: introducing Geochemical Data Toolkit (GCDkit). J Petrol 47:1255-1259. https://doi. org/10.1093/petrology/egl013

Jourdon A, Petit C, Rolland Y, Loury C, Bellahsen N, Guillot S, Le Pourhiet L, Ganino C (2017) New structural data on Late Paleozoic tectonics in the Kyrgyz Tien Shan (Central Asian Orogenic Belt). Gondwana Res 46:57-78. https://doi.org/10.1016/j. gr.2017.03.004

Kheraskova TN, Bush VA, Didenko AN, Samygin SG (2010) Breakup of Rodinia and early stages of evolution of the Paleoasian ocean. Geotectonics 44:3-24. https://doi.org/10.1134/S00168521100100 24 ((English version))

Kiselev VV (1984) Volcanic complex of Big Naryn. Bishkek, Ilim, pp 19-23. (in Russian)

Kiselev (2014) Chapter VI. New isotope-geochronological data to justify the age of the geodynamic complexes. In: Bakirov AB, Ges MD, Dzhenchuraeva RD, Kiselev VV, Maksumova RA, Mezgin IA, Pak NT, Sabelnikov SE, Sakiev KS (eds) Geodynamics and mineralization of the Tien Shan (Kyrgyzstan). Bishkek, Ilim, pp 228-258 (in Russian)

Korolev VG, Maksumova RA (1984) Pre-Cambrian tillites and tilloids of the Tien-Shan. Frunze, Ilim, 1984. P. 190 (in Russian)

Kiselev VV, Apayarov FKh, Komarevtsev VG, Tsyganok EN (1986) New data on uranium-lead age of the Tien-Shan stratified formations. In: Methods of isotope geology and geochronologic scale. Moscow. Nauka, pp. 215-225 (in Russian)

Kiselev VV, Apayarov FKh, Komarevtsev VT, Tsyganok EN, Lukashova EM (1993) Isotope age of zircons of the Tien Shan crystalline complexes. In: The Early Pre-Cambrian of Central Asian fold belt. St. Petersburg. Nauka, pp. 99-115 (in Russian)

Korolev VG (1956) Geological map of sheet K-43-95. Scale 1: 100 000. Report on the works of the Kokdzhar Geological Survey 1953-1956. Frunze, 1953 (survey report in Russian) 
Kröner A, Kovach V, Belousova E, Hegner E, Armstrong R, Dolgopolova A, Seltmann R, Alexeiev DV, Hoffmann JE, Wong J, Sun M, Cai K, Wang T, Tong Y, Wilde SA, Degtyarev KE, Rytsk E (2013) Reassessment of continental growth during the accretionary history of the Central Asian Orogenic Belt. Gondwana Res 25:103-125. https://doi.org/10.1016/j.gr.2012.12.023

Kröner A, Alexeiev DV, Kovach VP, Rojas-Agramonte Y, Tretyakov AA, Mikolaichuk AV, Xie H, Sobel ER (2017) Zircon ages, geochemistry and Nd isotopic systematics for the Palaeoproterozoic 2.3-1.8 Ga Kuilyu Complex, East Kyrgyzstan-the oldest continental basement fragment in the Tianshan orogenic belt. J Asian Earth Sci 135:122-135. https://doi.org/10.1016/j.jseae s.2016.12.022

Le Bas MJ, Le Maitre RW, Streckeisen A, Zanettin B (1986) A chemical classification of volcanic rocks based on the total alkali silica diagram. J Petrol 27:745-750. https://doi.org/10.1093/petro $\log / 27.3 .745$

Ludwig KR (2009) Isoplot/Ex version 4.0. A geochronological toolkit for Microsoft Excel: Berkeley Geochronology Center Special Publication.

Maniar PD, Piccoli PM (1989) Tectonic discrimination of Granitoids. Geol Soc Am Bull 101:635-643. https://doi.org/10.1130/00167606(1989)101\%3c0635:TDOG\%3e2.3.CO;2

McDonough WF, Sun SS (1995) The composition of the earth. Chem Geol 120:224-254. https://doi.org/10.1016/0009-2541(94)00140 $-4$

McDougall I, Harrison TM (1999) Geochronology and thermochronology by the ${ }^{40} \mathrm{Ar} /{ }^{49} \mathrm{Ar}$ method, 2nd edn. Oxford University Press, Oxford, p 269

Mikolaichuk AV, Djenchuraeva AV (2000) Middle-Paleozoic complexes of the Turkestan and Kazakh basins in the territory of Central Asia. General tectonic questions. In: Tectonics of Russia. Materials of the XXXIII Tectonic Meeting. Moscow; GEOS Publishing House pp 318-321 (in Russian)

Mikolaichuk AV, Apayarov FKh, Buchroithner MF, Chernavskaja ZI, Skrinnik LI, Ghes MD, Neyevin AV, Charimov TA (2008) Geological Map of Khan Tengri Massif. Explanatory Note. ISTC Project No. \#KR-920. Bishkek, 127 pp

Mikolaichuk AV, Lasovskyi V, Terbishalieva B, Seitkaziev N, Kmet L (2016) East Djetim-Too report and Map 1:50 000. Bishkek, 2016. NKGE, Pchankyi servey, 120 pp. (survey report in Russian)

Pearce JA (1996) A User's Guide to Basalt Discrimination Diagrams. In: Wyman DA (ed) Trace element geochemistry of volcanic rocks: applications for massive sulphide exploration. Geological Association of Canada, Short Course Notes, vol 12, pp 79-113

Peccerillo A, Taylor SR (1976) Geochemistry of Eocene calc-alkaline volcanic rocks from the Kastamonu area, Northern Turkey. Contrib Mineral Petrol 58:64-81. https://doi.org/10.1007/BF003 84745

Petrus JA, Kamber BS (2012) Vizual age: a novel approach to laser ablation ICP-MS U-Pb geochronology data reduction. Geostand Geoanal Res 46:247-270. https://doi.org/10.1111/ggr.2012.46. issue-4

Rojas-Agramonte Y, Kröner A, Alexeiev DV, Jeffreys T, Khudoley AK, Wong J, Geng H, Shu L, Semiletkin SA, Mikolaichuk AV, Kiselev VV, Yang J, Seltmann R (2014) Detrital and igneous zircon ages for supracrustal rocks of the Kyrgyz Tianshan and palaeogeographic implications. Gondwana Res 26:957-974. https://doi. org/10.1016/j.gr.2013.09.005

Rubtsov VI, Lopin AF(1984) Geological structure and minerals of K-43-71-A, B, V, G; K-43-72- A, B, V, G; K-43- 83- A, B, V, G; K-43-84- A, B, V, G sheets. Report of the Jilusu geological survey at a scale 1:50 000 carried out in 1977-1983. Archives of the State Geological Agency of the Kyrgyz Republic, Frunze

Safonova I (2017) Juvenile versus recycled crust in the Central Asian Orogenic Belt: Implications from ocean plate stratigraphy, blueschist belts and intra-oceanic arcs. Gondwana Res 47:6-27. https ://doi.org/10.1016/j.gr.2016.09.003

Sagyndykov KS, Sudorgin AA (1984) Djetim iron-ore basin of the Tien-Shan. Ilim, Frunze, p 215 ((in Russian))

Sagyndykov KS, Sudorgin AA, Apyshev TA (1988) New data on the stratigraphy of the Upper Precambrian of the Akshiirak ridge. Precambrian and Lower Paleozoic of the Tien Shan. Frunze, Ilim, pp 84-99 ((in Russian))

Şengör AMC, Natal'ln BA, Burtman VS (1993) Evolution of the Altaid tectonic collage and Palaeozoic crustal growth in Eurasia. Nature 364:299-307. https://doi.org/10.1038/364299a0

Schulz SS (1948) Analysis of the newest tectonics and the relief of the Tien Shan. New episode. T.3. Mockow, Geografgiz, 221 pp. (in Russian)

Sláma J, Košler J, Condon DJ, Crowley JL, Gerdes A, Hanchar JM, Horstwood MSA, Morris GA, Nasdala L, Norberg N, Schaltegger U, Schoene B, Tubrett MN, Whitehouse MJ (2008) Plešovice zircon - a new natural reference material for $\mathrm{U}-\mathrm{Pb}$ and $\mathrm{Hf}$ isotopic microanalysis. Chem Geol 249:1-45. https://doi.org/10.1016/j. chemgeo.2007.11.005

Steiger RH, Jäger E (1977) Subcommission on geochronology: convention on the use of decay constants in geo- and cosmochronology. Earth Planet Sci Lett 46:459-462. https://doi.org/10.1016/0012821X(77)90060-7

Terbishalieva B (2018) Geodynamic evolution of Big Naryn Complex, Middle Tianshan. Unpublished Master of Science thesis, $101 \mathrm{pp}$. University of Potsdam, Germany.

Thirlwall MF, Smith TE, Graham AM, Theodorou N, Hollings P, Davidson JP, Arculus RJ (1994) High field strength element anomalies in arc lavas: source or process? J Petrol 35:819-838. https://doi.org/10.1093/petrology/35.3.819

Tunheng A, Hirata T (2004) Development of signal smoothing device for precise elemental analysis using laser ablation-ICPmass spectrometry. J Anal Atomic Spectrom 19:942. https://doi. org/10.1049/b402494a

Uto K, Ishizuka O, Matsumoto A, Kamioka H, Togashi S (1997) Laser-heating ${ }^{40} \mathrm{Ar} /{ }^{49} \mathrm{Ar}$ dating system of the Geological Survey of Japan: system outline and preliminary results. Bull Geol Surv Japan 48:24-46

Whitney DL, Evans BW (2010) Abbreviations for names of rock-forming minerals. Am Mineral 95:185-187. https://doi.org/10.2138/ am.2010.3371

Zuleger E, Erzinger J (1988) Determination of the REE and Y in silicate materials with ICP-AES. Fresenius' Zeitschrift für analytische Chemie 442:140-144. https://doi.org/10.1007/BF004 70631 